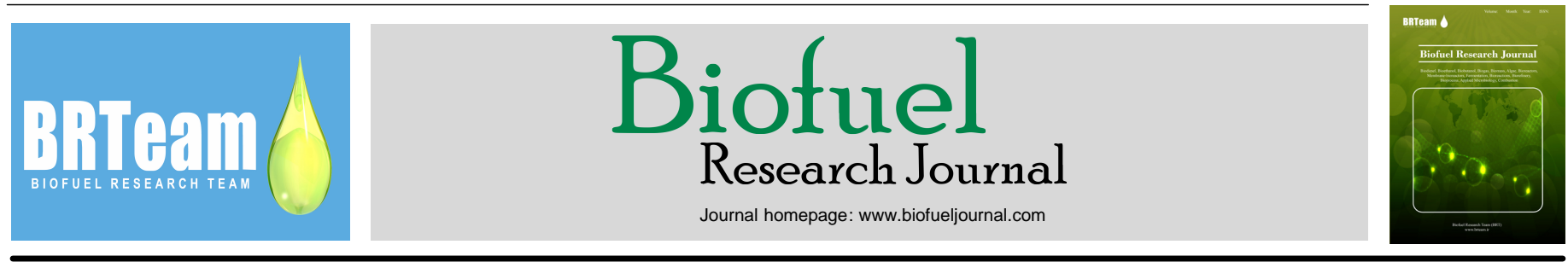

Review Paper

\title{
Advanced nanocomposite membranes for fuel cell applications: a comprehensive review
}

Kolsoum Pourzare ${ }^{1}$, Yaghoub Mansourpanah ${ }^{1,2, *}$, Saeed Farhadi $^{1}$

${ }^{1}$ Membrane Research Laboratory, Lorestan University, Khorramabad, P.O. Box 68137-17133, Iran.

${ }^{2}$ Membrane Separation Technology (MST) Group, Biofuel Research Team (BRTeam), Karaj, Iran.

\section{HIGHLIGHTS}

$>$ Nanocomposite proton exchange membranes based on different fillers have been comprehensively discussed.

Analytical methods used for proton exchange membranes properties have been reviewed.

> Properties of polymer composites based on a variety of nanoparticles have been scrutinized.

\section{GRAPHICAL ABSTRACT}
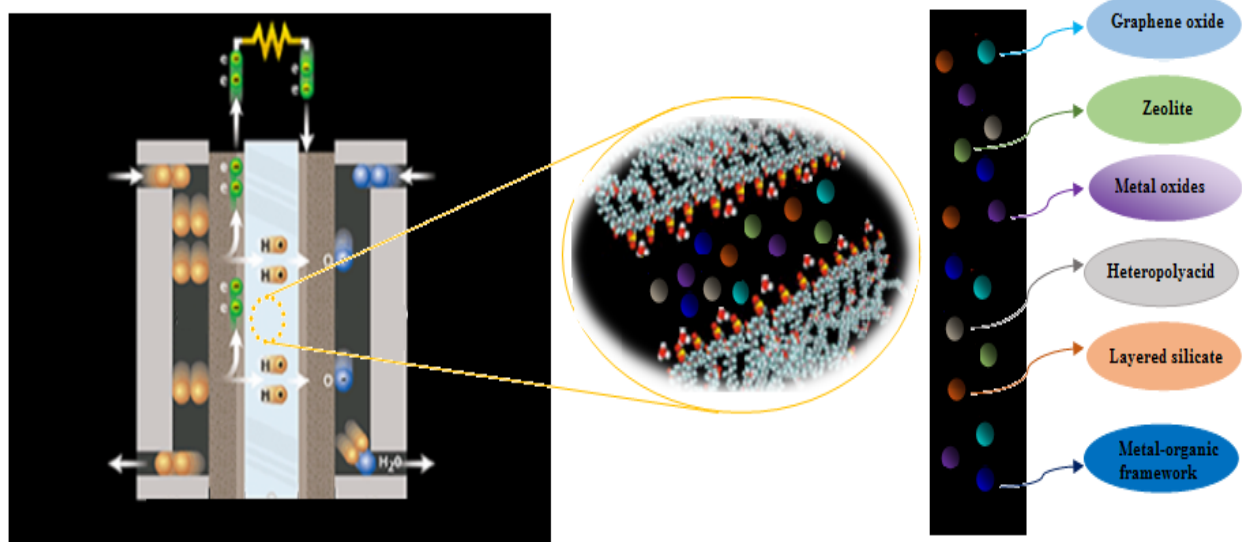

\section{ARTICLE INFO}

\section{Article history:}

Received 15 September 2015

Received in revised form 1 November 2016

Accepted 7 November 2016

Available online 1 December 2016

\section{Keywords:}

Organic-inorganic nanocomposite

Proton exchange membrane

Inorganic fillers

Fuel cell

\begin{abstract}
Combination of inorganic fillers into organic polymer membranes (organic-inorganic hybrid membranes) has drawn a significant deal of attention over the last few decades. This is because of the incorporated influence of the organic and inorganic phases towards proton conductivity and membrane stability, in addition to cost decline, improved water retention property, and also suppressing fuel crossover by increasing the transport pathway tortuousness. The preparation methods of the composite membranes and the intrinsic characteristics of the used particles as filler, such as size, type, surface acidity, shape, and their interactions with the polymer matrix can significantly affect the properties of the resultant matrix. The membranes currently used in proton exchange membrane fuel cells (PEMFCs) are perfluorinated polymers containing sulfonic acid, such as Nafion ${ }^{\circledR}$. Although these membranes possess superior properties, such as high proton conductivity and acceptable chemical, mechanical, and thermal stability, they suffer from several disadvantages such as water management, CO poisoning, and fuel crossover. Organic-inorganic nanocomposite PEMs offer excellent potentials for overcoming these shortcomings in order to achieve improved FC performance. Various inorganic fillers for the fabrication of composite membranes have been comprehensively reviewed in the present article. Moreover, the properties of polymer composites containing different nanoparticles have been thoroughly discussed.
\end{abstract}

* Corresponding author at: Tel.: +986633120611

E-mail address: mansourpanah.y@lu.ac.ir,mansourpanah.y@gmail.com

Please cite this article as: Pourzare K., Mansourpanah Y., Farhadi S. Advanced nanocomposite membranes for fuel cell applications: a comprehensive review. Biofuel Research Journal 12 (2016) 496-513. DOI: 10.18331/BRJ2016.3.4.4 


\section{Contents}

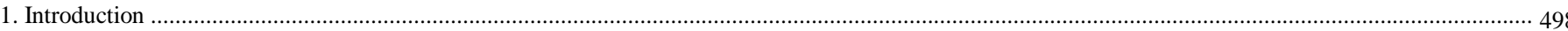

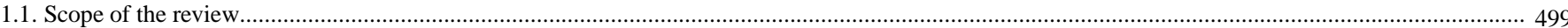

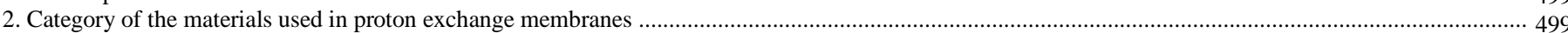

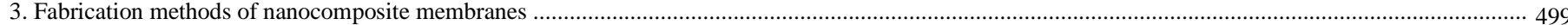

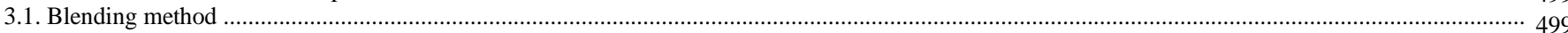

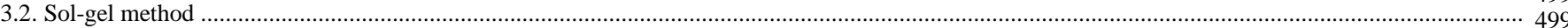

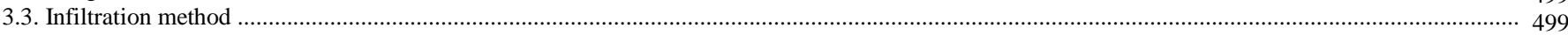

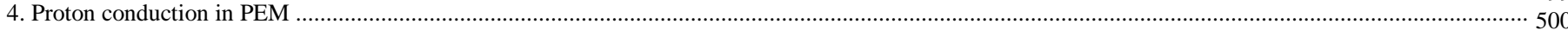

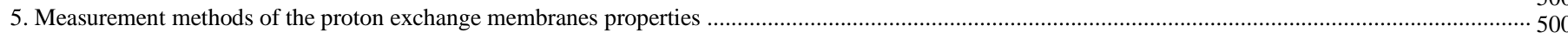

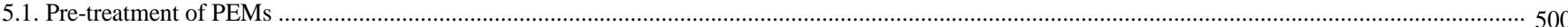

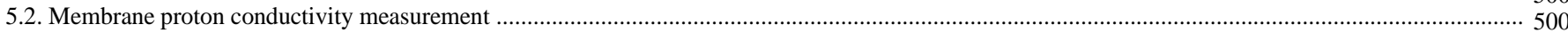

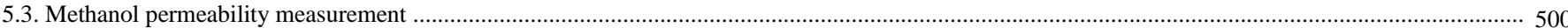

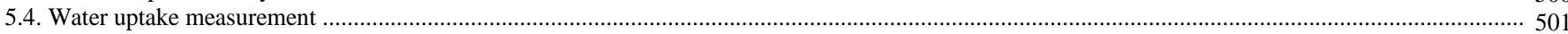

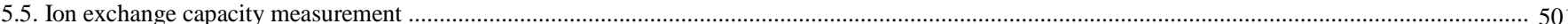

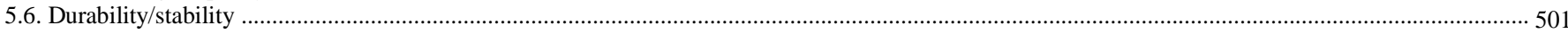

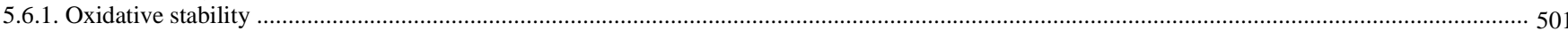

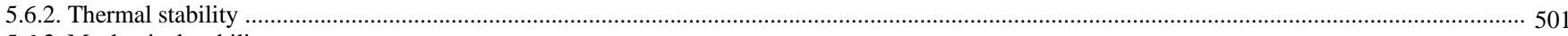

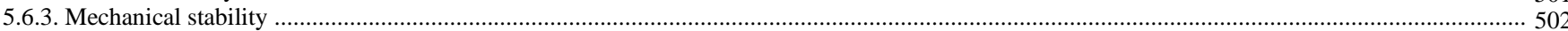

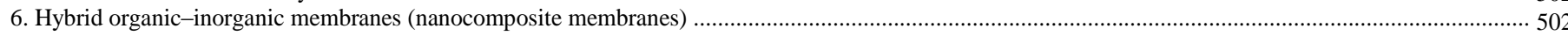

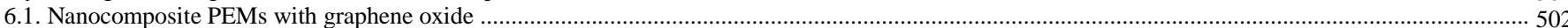

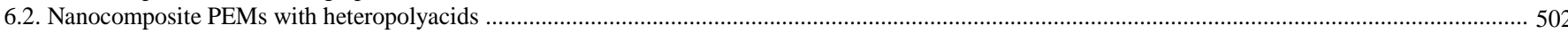

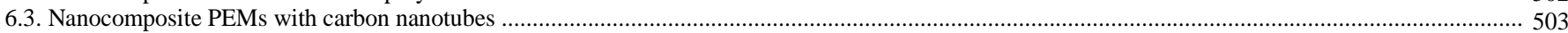

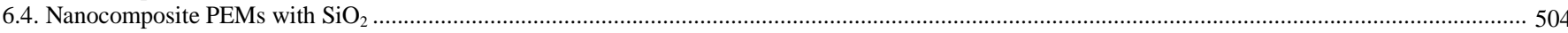

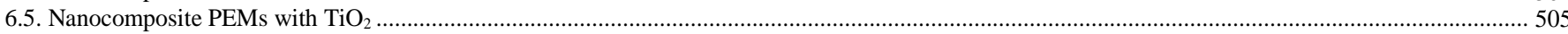

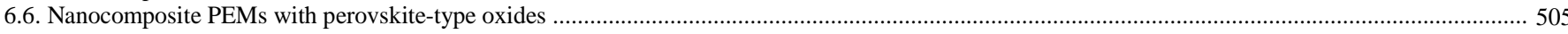

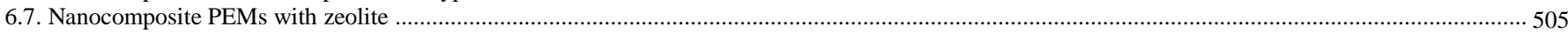

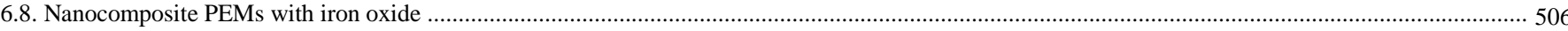

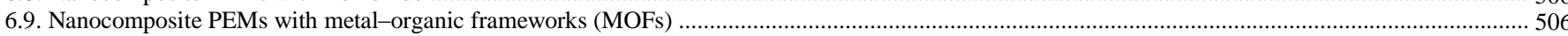

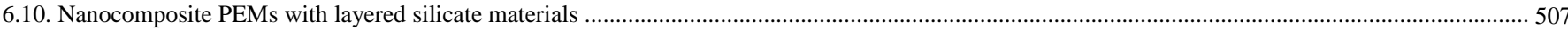

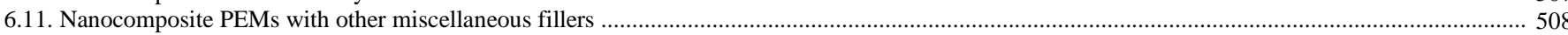

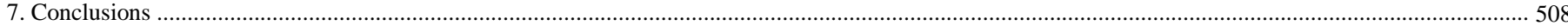

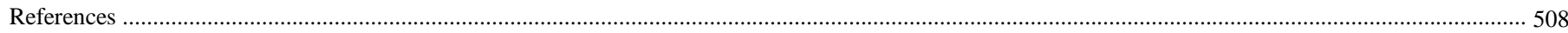

\begin{tabular}{|c|c|c|c|}
\hline \multicolumn{4}{|l|}{ Abbreviations } \\
\hline $\mathrm{AFC}$ & Alkaline fuel cell & PAMPS & Poly(2-acrylamido-2-methylpropane sulfonic acid) \\
\hline ATMP & Amino trimethylene phosphonic acid & PBI & Poly(benzimidazole) \\
\hline CCVD & Catalytic chemical vapour deposition & PDASA & 1,4-phenylenediamine-2-sulfonic acid \\
\hline CNTs & Carbon nanotubes & PDHC & 1,4-phenyldiamine hydrochloride \\
\hline CPs & Coordination polymers & PEEK & poly(ether ether ketone) \\
\hline CTS-SPIONs & Chitosan coated superparamagnetic iron oxide nanoparticles & PEM & Proton exchange membrane \\
\hline CTS & Chitosan & PEMFC & Proton exchange membrane fuel cell \\
\hline CWs & Cellulose whiskers & POMs & Polyoxometalates \\
\hline DI water & Deionized water & PPO & poly(2,6-dimethyl-1,4-phenylene oxide) \\
\hline DMA & Dynamical mechanical analysis & PTA & Phosphotungstic acid \\
\hline DMFC & Direct methanol fuel cell & PVA & Poly(vinyl alcohol) \\
\hline DSC & Differential scanning calorimetry & PVP & Polyvinyl pyrrolidone \\
\hline $\mathrm{EFC}$ & Enzymatic fuel cell & RH & Relative humidity \\
\hline EIS & Electrochemical impedance spectroscopy & SBUs & Secondary building units \\
\hline FC & Fuel Cell & SHNTs & Sulfonated halloysite nanotubes \\
\hline $\mathrm{GC}$ & Gas chromatography & SGO & Sulfonated graphene oxide \\
\hline GDLs & Gas diffusion layers & SNP & Sodium nitroprusside \\
\hline GO & Graphene oxide & SOFC & Solid oxide fuel cell \\
\hline GPTMS & (3-glycidoxypropyl)-methyldiethoxysilane & SPEEK & Sulfonated poly(ether ether ketone) \\
\hline HR-TEM & High resolution transmission electron microscopy & SPAES & Sulfonated poly(arylene ether sulfone \\
\hline IEC & Ion exchange capacity & SPAEK-COOH & Sulfonated poly(arylene ether ketone) \\
\hline LBL & Layer-by-layer & SPS & Sulfonated poly(styrene) \\
\hline MCFC & Molten carbonate fuel cell & SPSU & Sulfonated polysulfone \\
\hline MeOEGMA & Monomethoxy oligoethylene glycol methacrylate & SW & Membrane swelling \\
\hline MFC & Microbial fuel cell & SWy & Smectite clays \\
\hline MOFs & Metal-organic frameworks & TEOS & Tetra ethyl orthosilicate \\
\hline MPTMS & 3-mercaptopropyltrimethoxysilane & TGA & Thermogravimetric analyzer \\
\hline MRI & Magnetic resonance imaging & TS & Sulfated nanotitania \\
\hline MWNTs & Multi-walled carbon nanotubes & WU & Water uptake \\
\hline NAFB & Nafion ${ }^{\circledast} /$ acid functionalized zeolite beta & ZIF-8 & Zeolitic imidazolate framework- 8 \\
\hline NMPA & Nitrilotri(methyl triphosphonic acid) & $\mathrm{ZrNT}$ & Zirconium oxide nanotube \\
\hline OCV & Open circuit voltage & $\mathrm{ZrP}$ & Zirconium phosphate \\
\hline
\end{tabular}

Please cite this article as: Pourzare K., Mansourpanah Y., Farhadi S. Advanced nanocomposite membranes for fuel cell applications: a comprehensive review. Biofuel Research Journal 12 (2016) 496-513. DOI: 10.18331/BRJ2016.3.4.4 


\section{Introduction}

Global energy consumption is projected to increase by $56 \%$ by the year 2040 as a result of various factors such as rapid urbanization and population growth. In response to this growing energy demand, several alternative energy technologies have been proposed, among which fuel cell (FC) technology has attracted considerable attention (Ramaswamy et al., 2014). FC technology is identified as promising electric energy generators that could furnish clean and efficient energy for stationary applications, transportation, and portable power applications in the $21^{\text {st }}$ century (Carrette et al., 2001; Steele and Heinzel, 2001; Jacobson et al., 2005). Technically, an FC is an electrochemical device that continuously converts chemical energy fuel (such as hydrogen, natural gas, methanol, ethanol, etc.) into electric energy (and some heat) as long as fuel and oxidant are supplied (Zhang et al., 2012). The utilisation of liquid fuels such as ethanol and methanol in FCs would reduce the requirements of establishing totally new infrastructure as required for hydrogen as a fuel source (Zakaria et al., 2016). Furthermore, both methanol and ethanol are considered renewable fuels (biofuels) when generated from biomass resources. It is worth quoting that currently bioethanol dominates the global biofuel production capacity and can be produced in bulk from biomass feedstocks via a fermentation process (Badwal et al., 2015; Zakaria et al., 2016).

FCs diminish power loses by avoiding the intermediate steps required in similar diesel-powered generators (Mishra et al., 2012). FCs are commonly named and classified based on the nature of the electrolyte used in the cell as follows: proton exchange membrane fuel cell (PEMFC), direct methanol fuel cell (DMFC), phosphoric acid fuel cell (PAFC), molten carbonate fuel cell (MCFC), solid oxide fuel cell (SOFC), alkaline fuel cell (AFC), microbial fuel cell (MFC), and enzymatic fuel cell (EFC), and in general, two main classes can be defined: i) low temperature FCs operating at temperatures lower than $250{ }^{\circ} \mathrm{C}$ (such as proton exchange membrane fuel cells (PEMCs)) and ii) high temperature FCs operating at temperatures ranging from $600{ }^{\circ} \mathrm{C}$ up to $1100{ }^{\circ} \mathrm{C}$ (such as solid oxide fuel cells (SOFCs)) (Laberty-Robert et al., 2011). Table 1 summarizes the operating properties of the main types of FCs (Sharaf and Orhan, 2014).

Table1.

Typical electrolyte and operating properties of main fuel cell technologies (modified from (Sharaf and Orhan, 2014)).

\begin{tabular}{|c|c|c|c|c|c|}
\hline Fuel cell type & $\begin{array}{l}\text { Typical } \\
\text { electrolyte }\end{array}$ & Typical fuel & $\begin{array}{c}\text { Operation } \\
\text { temperature } \\
\left({ }^{\circ} \mathrm{C}\right)\end{array}$ & $\begin{array}{c}\text { Electrical } \\
\text { efficiency } \\
(\%)\end{array}$ & $\begin{array}{l}\text { Charge } \\
\text { carrier }\end{array}$ \\
\hline $\begin{array}{l}\text { Proton exchange } \\
\text { membrane fuel } \\
\text { cell (PEMFC) }\end{array}$ & $\begin{array}{l}\text { Perfluorosulfonic } \\
\text { acid }\end{array}$ & $\mathrm{H}_{2}$ & $50-80$ & 60 & $\mathrm{H}^{+}$ \\
\hline $\begin{array}{l}\text { Phosphoric acid } \\
\text { fuel cell (PAFC) }\end{array}$ & $\begin{array}{l}\text { Phosphoric acid } \\
\left(\mathrm{H}_{3} \mathrm{PO}_{4}\right) \text { ins ilicon } \\
\text { carbide }(\mathrm{SiC})\end{array}$ & $\mathrm{H}_{2}$ & $160-220$ & 40 & $\mathrm{H}^{+}$ \\
\hline $\begin{array}{l}\text { Alkaline fuel } \\
\text { cell (AFC) }\end{array}$ & $\begin{array}{l}\text { aqueous solution } \\
\text { of potassium } \\
\text { hydroxide }(\mathrm{KOH})\end{array}$ & $\mathrm{H}_{2}$ & $50-200$ & 60 & $\mathrm{OH}$ \\
\hline $\begin{array}{l}\text { Molten } \\
\text { carbonate fuel } \\
\text { cell (MCFC) }\end{array}$ & $\begin{array}{l}\text { Solution of } \\
\left(\mathrm{Li}_{2} \mathrm{CO}_{3}, \mathrm{Na}_{2} \mathrm{CO}_{3} \text {, }\right. \\
\left.\mathrm{K}_{2} \mathrm{CO}_{3}\right) \text { in } \\
\text { Lithium aluminate } \\
\left(\mathrm{LiAlO}_{2}\right)\end{array}$ & $\mathrm{CH}_{4}$ & $600-700$ & $45-50$ & $\mathrm{CO}_{3}^{2-}$ \\
\hline $\begin{array}{l}\text { Solid oxide fuel } \\
\text { cell (SOFC }\end{array}$ & $\begin{array}{l}\text { Yttria- stabilized } \\
\text { zirconia (YSZ) }\end{array}$ & $\mathrm{H}_{2}$ & $800-1000$ & 60 & $\mathrm{O}^{2-}$ \\
\hline $\begin{array}{l}\text { Direct methanol } \\
\text { fuel cell } \\
\text { (DMFC) }\end{array}$ & $\begin{array}{l}\text { Perfluorosulfonic } \\
\text { acid }\end{array}$ & $\mathrm{CH}_{3} \mathrm{OH} / \mathrm{H}_{2} \mathrm{O}$ & $90-120$ & 60 & $\mathrm{H}^{+}$ \\
\hline $\begin{array}{l}\text { Microbial fuel } \\
\text { cell (MFC) }\end{array}$ & $\begin{array}{l}\text { Ion exchange } \\
\text { membrare }\end{array}$ & $\begin{array}{l}\text { Wastewater } \\
\text { glucose, } \\
\text { acetate }\end{array}$ & $20-60$ & 65 & $\mathrm{H}^{+}$ \\
\hline
\end{tabular}

Among the various kinds of FCs, PEMFCs have attracted a great deal of attention and have provided the strongest motivation for technological enlargement owing to their unique features such as ambient temperature working conditions, fast start-up, high specific power density, and easy portability (Steele and Heinzel, 2001; Narayanamoorthy et al., 2012). PEMFCs themselves can also be classified into two groups: LT-PEMFC (operation temperature between $60-80{ }^{\circ} \mathrm{C}$ ) and HT-PEMFC (operation temperature between $100-200{ }^{\circ} \mathrm{C}$ ). There are some intrinsic problems with operating PEMFCs at low temperatures (around $80^{\circ} \mathrm{C}$ ) such as heat and water management and $\mathrm{CO}$ poisoning while the HT-PEMFCs are well capable of overcoming these drawbacks (Chandan et al., 2013; Authayanun et al., 2015). As schematically shown in Figure 1a, a PEMFC is composed of the anode and cathode flow field plates, gas diffusion layers (GDLs), catalyst layers (CLs), and proton exchange membrane (PEM) (Wang et al., 2011; Ye and Zhan, 2013). A single FC is only able to produce a certain voltage and current. In order to obtain a higher voltage and current or power, FCs are connected in either series or parallel, called stacks (Wang et al., 2011), as shown in Figure 1b. The important properties of PEM as central component in hydrogen and methanol FC systems include high proton conductivity, low electronic conductivity, high mechanical and thermal stability, good oxidative and hydrolytic stability, low fuel and oxidant permeability, low cost, good dimensional, and morphological stability (Kraytsberg and Ein-Eli, 2014).

Nafion ${ }^{\circledR}$ as the most common and commercially available PEM for PEMFC, DMFC, and BFC possess wonderful properties, such as high proton conductivity and good chemical, mechanical, and thermal stability.
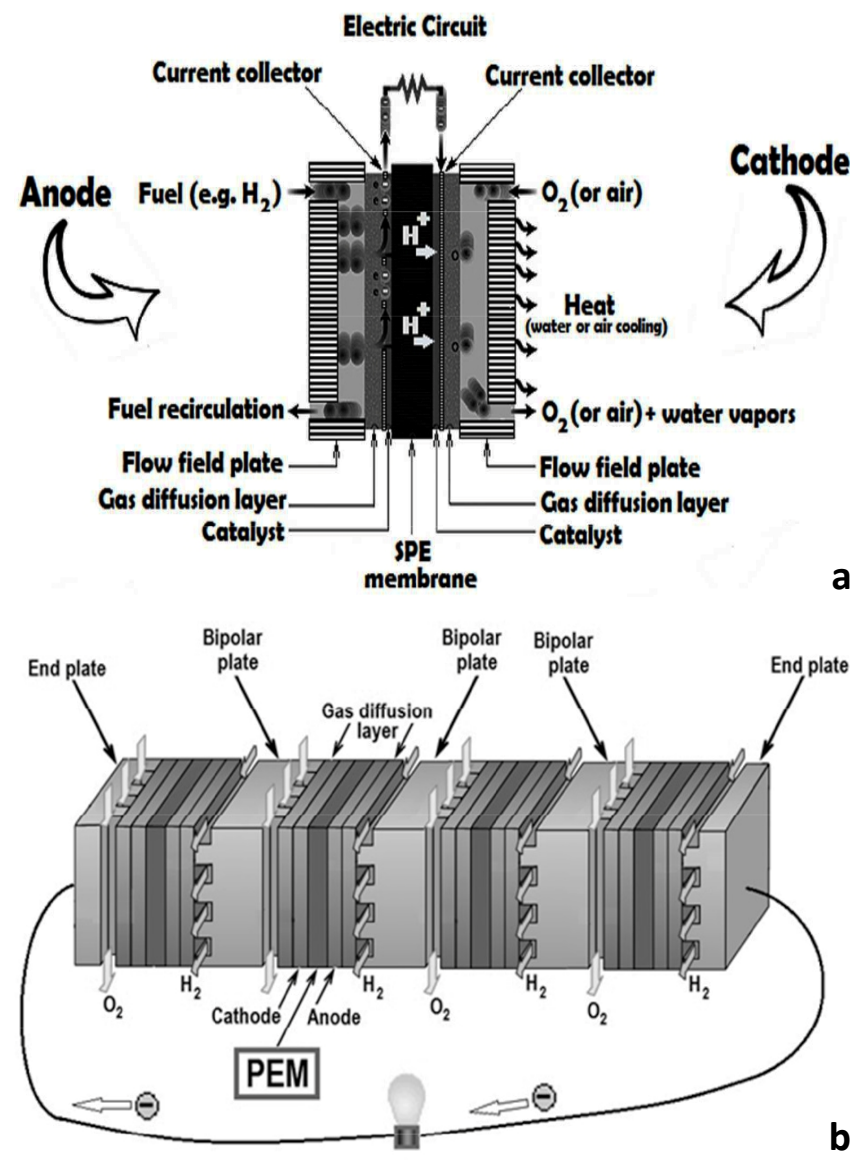

PEM FC stack

Fig. 1. (a) Schematic representation of a PEMFC design and (b) PEMFC stack (Kraytsberg and Ein-Eli, 2014). Copyright (2016), reprinted with permission from ACS.

Despite their favourable features, these membranes have several disadvantages, i.e., high cost, fuel permeability, and diminished performance accompanying with dehydration at temperatures above $80{ }^{\circ} \mathrm{C}$ (Hickner et al., 2004). In recent years, many studies have been focused on developing proton conducting membranes for operation at higher temperatures under lower humidification conditions to overcome the above-mentioned drawbacks aiming at generating higher FC performance compared with perfluorinated ionomers (Jalani et al., 2005; Ramani et al., 2005a; Jung et al., 2006; Ren et al., 2006; Sacca et al., 2006; Zhai et al., 
2006; Zeng et al., 2007; Park et al., 2008). Basically, to achieve this goal, there are two strategies: 1) fabrication of polymeric membranes based on hydrocarbon polymers such as poly(benzimidazole) (PBI), poly(arylene ether sulfone) (PSU), poly(styrene) (PS), poly(ether ether ketone) (PEEK), poly(ether sulfone) (PES), poly(2,6-dimethyl-1,4-phenylene oxide) (PPO), etc. (Rikukawa and Sanui, 2000; Gil et al., 2004; Xu et al., 2008; Ahmad et al., 2010), and 2) preparation of composite membranes through the application of inorganic micro-/nanoparticle (Di et al., 2015). The use of organic-inorganic composite membranes by incorporating inorganic fillers, in the ionomer matrix can significantly affect the properties of the matrix. The composite membranes exhibit suppressed fuel crossover, improved thermal, mechanical, dimensional, and oxidative stability. The properties of polymer composites depend on the type of nanoparticles that are incorporated, their size and shape, as well as their concentration and their interactions with the polymer matrix. Dispersion of inorganic nanoparticles in a polymer matrix usually leads to nanoparticles agglomerate due to their specific surface area and volume effects while it can also result in a reduction in proton conductivity due to decreased number of sulfonate groups per unit volume. These problems can be overcome by modification of the surface of the inorganic particles (Laberty-Robert et al., 2011; Kango et al., 2013; Liu et al., 2015).

\subsection{Scope of the review}

Various inorganic fillers have been used in many polymer membranes developed for PEMFC. The objective of this review is to highlight these fillers and their impacts on proton conductivity, methanol permeability, water uptake, mechanical and thermal properties and cell performance of the resulting nanocomposite membranes.

\section{Category of the materials used in PEMs}

Generally, the materials used in synthesizing the polymer electrolyte membranes, also known as PEMs, can be categorized into five different groups: perfluorinated ionomers, partially-fluorinated polymers, nonfluorinated hydrocarbons, non-fluorinated membranes with aromatic backbones, and acid-base complexes (Table 2). Several reviews are available describing the materials used in the synthesis of the polymer electrolyte membranes (Peighambardoust et al., 2010; Dupuis, 2011; Awang et al., 2015).

\section{Fabrication methods of nanocomposite membranes}

Among a variety of approaches applied to incorporate inorganic fillers into an ionomer matrix, blending, infiltration (also called "in situ method"), and sol-gel approach (Tripathi and Shahi, 2011; Li et al., 2013), have received a great deal of attention owing to their wide availability which are described in the following sections.

\subsection{Blending method}

The simplest method for the fabrication of polymer/inorganic nanocomposites is direct mixing of the nanoparticles into the polymer matrix. The mixing can be done by melt blending or solution blending. Filler agglomeration is the main difficulty faced in the blending method which can be overcome by the modification of the surface of the inorganic particles (Fig. 2a).

\subsection{Sol-gel method}

The sol-gel method is a low temperature synthesis method and has been extensively used to synthesize organic-inorganic nanocomposites since the 1980s (Fig. 2b). This process is generally done by hydrolysis and condensation reactions of metal alkoxides, $\mathrm{M}(\mathrm{OR})_{n}(\mathrm{M}=\mathrm{Si}, \mathrm{Ti}, \mathrm{Zr}, \mathrm{VO}, \mathrm{Zn}$, $\mathrm{Al}, \mathrm{Sn}, \mathrm{Ce}, \mathrm{Mo}, \mathrm{W}$, etc. and $\mathrm{R}=\mathrm{Me}, \mathrm{Et}, \ldots$. ) inside a polymer dissolved in non-aqueous or aqueous solutions. These reactions are as follows (Eqs. 1 and 2) (Pomogailo, 2005):

$\mathrm{M}(\mathrm{OR})_{4}+4 \mathrm{H}_{2} \mathrm{O} \rightarrow \mathrm{M}(\mathrm{OH})_{4}+4 \mathrm{ROH}$

Eq. 1
Table 2.

The chemical structure of some of the most commonly-used polymers in PEMs

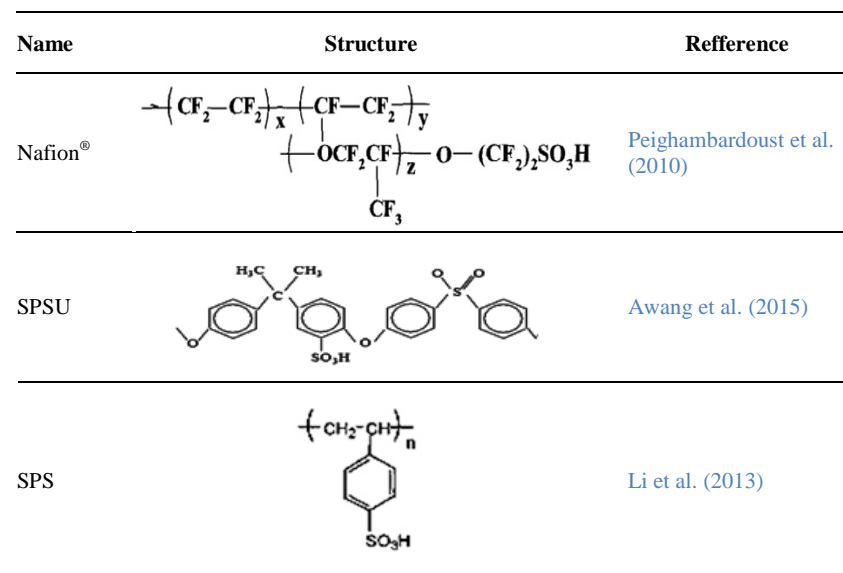

SPEEK
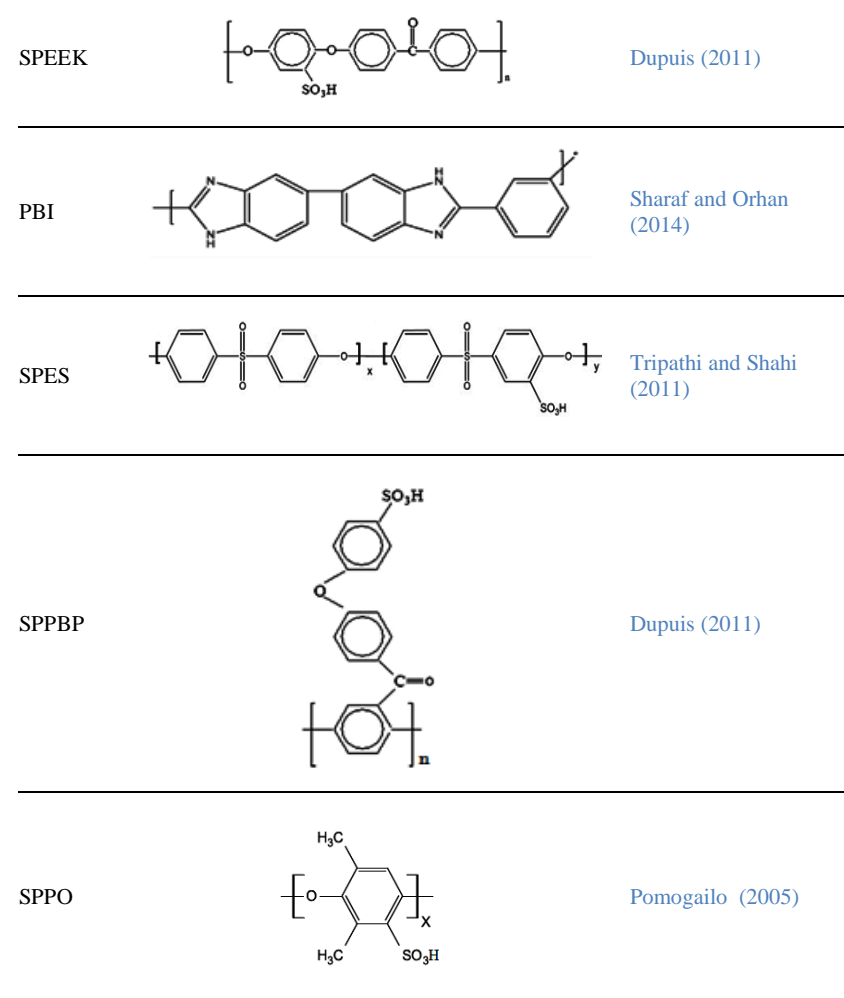

$\mathrm{mM}(\mathrm{OH})_{4} \rightarrow\left(\mathrm{MO}_{2}\right) \mathrm{m}+2 \mathrm{mH}_{2} \mathrm{O}$

Silicon alkoxides are not very sensitive to hydrolysis and gelation may take place within several days when pure water is added. Therefore, hydrolysis and condensation proceed without catalysts for non-silicate metal alkoxides, whereas acid or base catalysts are required for silicon alkoxides (Livage, 2004). Four factors affect the kinetics reactions and consequently the final structure and properties of the product, including: the molar ratio of water/silane, the tape catalyst, temperature, and the solvent nature which were briefly described previously by Bounor-Legaré and Cassagnau (2014).

\subsection{Infiltration method}

In-situ or infiltration methods have also been used to prepare organicinorganic nanocomposites, in which the precursors of inorganic fillers 

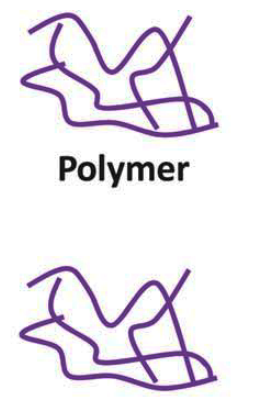

Polymer

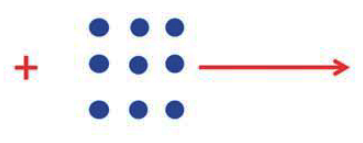

Filler

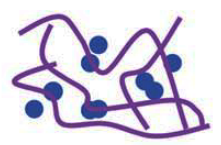

(a) Physical blending method

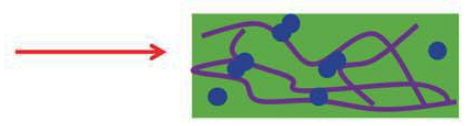

Composite membrane $+\quad \begin{aligned} & ::::: \text { Hydrolysis } \\ & :::::\end{aligned}$

precursor

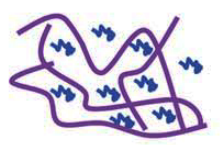

$\stackrel{\text { condensation }}{\longrightarrow}$

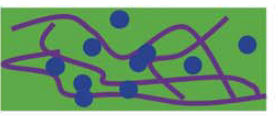

Composite membrane

(b) Sol-gel method

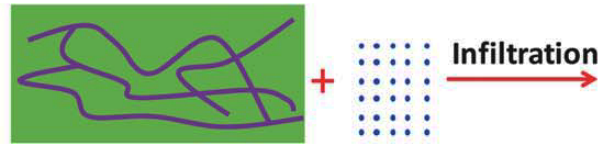

Swollen membrane precursor
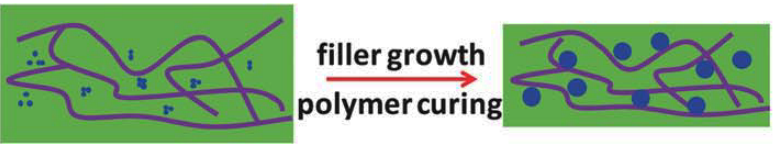

\section{(c) Infiltration method}

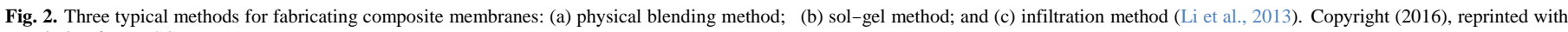
permission from RSC.

infiltrate into a swollen or hydrogel-like polymer matrix (to increase the pore or void volume before infiltration), and then the nanocomposite membranes are obtained through filler growth, removing the impurities, and polymer curing. Meanwhile, the isolation effect caused by the polymer network can hinder the undesirable agglomeration of nanoparticles and simultaneously lead to controled particles size and uniform distribution (Fig. 2c).

\section{Proton conduction in PEMs}

The high proton conductivity of Nafion ${ }^{\circledR}$ at low temperatures and its lower conductivity at high temperatures have prompted many researchers to investigate its proton conduction mechanism (Mishra et al., 2012). Proton conductivity is a major parameter to evaluate the membrane performance. It has been reported that proton conductivity depends on the degree of sulfonation, pre-treatment of the membrane, water uptake, as well as ambient relative humidity (RH) and temperature (Jaafar et al., 2009). Proton conduction through membranes follows two types of mechanisms: Vehicle mechanism and Grotthuss mechanism. In the Grotthuss mechanism, the protons jump from one ionic site $\left(\mathrm{H}_{3} \mathrm{O}^{+} . \mathrm{SO}_{3}{ }^{-}\right)$to another while in the vehicle mechanism, protons attach to free water molecules and diffuse. Proton conduction is accompanied with activation energies; i.e., $0.1<$ Eact $<0.4 \mathrm{eV}$ by the Grotthuss mechanism and Eact $>0.5 \mathrm{eV}$ by vehicle mechanism (Ren et al., 2013). A schematic representation of the two mechanisms is shown in Figure 3 .

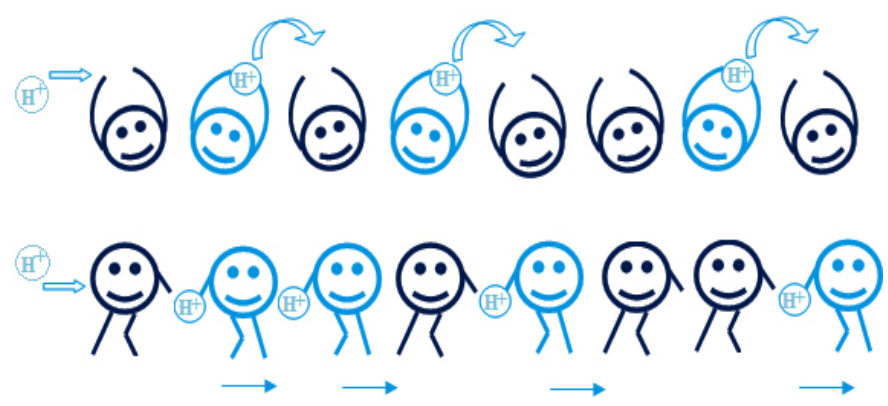

Fig. 3. Illustration of proton conduction models the Grotthuss mechanism (top) and the vehicle mechanism (bottom). Adopted from Ren et al. (2013).

\section{Measurement methods of the PEMs properties}

\subsection{Pre-treatment of PEMs}

In order to measure the PEMs properties, they should be in $\mathrm{H}$-form and free from impurities. Therefore, PEMs are activated by chemical treatments prior to analyses. Commonly, membranes are first soaked into a $\mathrm{H}_{2} \mathrm{O}_{2}$ solution, followed by treatment with a mixture of water and $\mathrm{H}_{2} \mathrm{SO}_{4}$ under continuous stirring. The membranes are then washed with deionized water (DI) water (Neelakandan et al., 2014; Dutta et al., 2015). However, Nair's group suggested that the introduction of harsh conditions such as $\mathrm{H}_{2} \mathrm{O}_{2}$ and acid treatment may destroy or disrupt the structure of the layered inorganic materials in the polymer matrix (Hudiono et al., 2009).

\subsection{Membrane proton conductivity measurement}

The proton conductivity of membranes is calculated by the electrochemical impedance spectroscopy (EIS) and can be measured in two directions; i.e., in-plane or through-plane (Tang et al., 2012), by either four-probe or two-probe method. Conductivity $(\sigma)$ is calculated using the following equation (Eq. 3):

$\sigma=\frac{L}{R A}$

For the in-plane test, $\mathrm{L}$ is the distance between the two electrodes and $\mathrm{A}$ is the cross-sectional area of the membrane; for the through-plane test, $\mathrm{L}$ is the thickness of the membrane and $\mathrm{A}$ is the overlap area of the two electrodes. $\mathrm{R}$ is the impedance of the membrane in Nyquist plot, which is determined from the intercept of the impedance curve with the real axis for through-plane test (Silva et al., 2004; Luan et al., 2008) and from the frequency at the minimum imaginary response for the in-plane experiment (Choi et al., 2008).

\subsection{Methanol permeability measurement}

Methanol permeability is the product of the diffusion coefficient and the sorption coefficient in which the diffusion coefficient reflects the effect of a surrounding environment on the molecular motion of the permeate and the sorption coefficient correlates with the concentration of a component in the fluid phase (Marx et al., 2002; Kumar et al., 2009). A 
proton conducting membrane with low methanol permeability is required for DMFC. Because methanol transport through the membranes causes loss of fuel, reduced fuel efficiency, reduced cathode voltage and cell performance, and excess thermal load in the cell which can be controlled by factors such as the hydrophilic channel size, water uptake, membrane compaction, and other operating conditions (Won et al., 2003; Li and Yang, 2009). Methanol permeability is determined by a side-by-side cell, one side is filled with a methanol solution in DI water (side A) while pure water is placed in the other side (side B). The solutions in both compartments are continuously stirred with a magnetic stirrer during the experiment to ensure homogeneity (see Fig. 4). Several spectroscopic techniques have been used to measure methanol concentration in the water compartment. For example Chang's and Javanbakht' groups recorded methanol concentration in the side B using a density meter (Chien et al., 2013; Beydaghi et al., 2015). Recently, the crossover methanol (from side A to side B) has been examined by UV-vis spectroscopic technique using sodium nitroprusside (SNP) as chromogenic reagent. In fact, SNP is a mixture of sodium nitroprusside, potassium ferrocyanide, $\mathrm{NaOH}$, and water in a certain proportion (Das et al., 2014; Dutta et al., 2015). The concentration of the methanol in side B can also be measured by gas chromatography (GC) method (Shahi, 2007; Hasanabadi et al., 2011). Methanol permeability using GC is determined as follows (Eq. 4):

$C_{\mathrm{B}}(t)=\frac{A P}{L V_{B}} C_{A}\left(t-t_{0}\right)$

where, $C_{B}(t)$ and $C_{A}$ are the concentrations of methanol in side $\mathrm{A}$ and $\mathrm{B}$ $(\mathrm{mol} \mathrm{L}-1)$, respectively, $\mathrm{P}$ is methanol permeability $\left(\mathrm{cm}^{2} \mathrm{~s}^{-1}\right), \mathrm{V}_{\mathrm{B}}$ is the volume of DI water in side $\mathrm{B}\left(\mathrm{cm}^{3}\right), \mathrm{L}$ is the thickness of the membrane $(\mathrm{cm})$, and A is the membrane area $\left(\mathrm{cm}^{2}\right)$. In other studies, cyclic voltammograms (CV) method (Escudero-Cid et al., 2015) and refractometry (Neelakandan et al., 2014) have also been used for measuring methanol concentration.

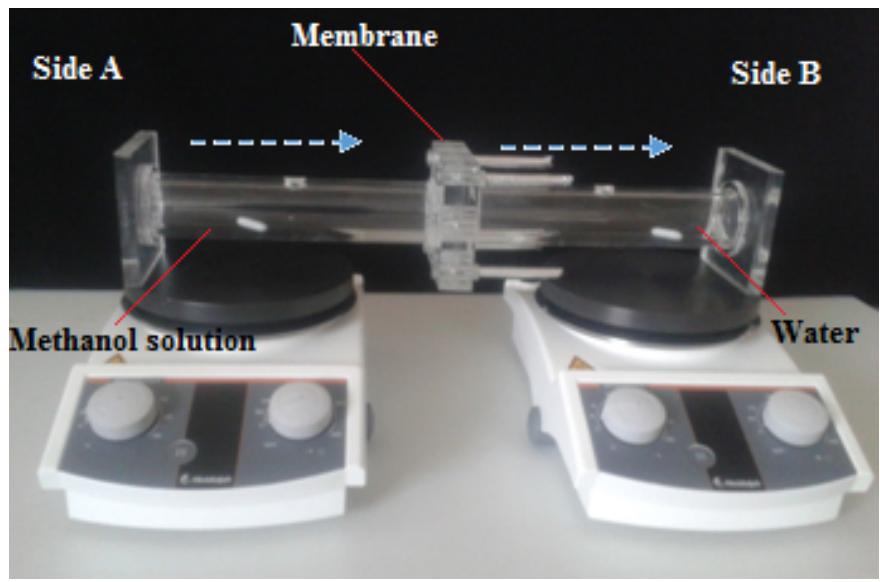

Fig. 4. A schematic illustration of the diffusion cell utilized for analyzing methanol crossover through membranes.

\subsection{Water uptake measurement}

The water uptake of the membranes is defined as mass ratio of the absorbed water to that of the dry membrane (Xi et al., 2007). Before measurements, membrane samples are dried at $80{ }^{\circ} \mathrm{C}$ for $12 \mathrm{~h}$, weighed, and are then soaked in DI water at room temperature for $24 \mathrm{~h}$. The samples whose surface water is fully hydrated are blotted by tissue papers and weighted immediately. The water uptake of the membranes is calculated using Equation 5:

$W U(\%)=\frac{M_{w e t}-M_{d r y}}{M_{d r y}} \times 100$ where, $M_{\text {wet }}$ and $M_{d r y}$ are the weights of the wet and dry membranes, respectively. A high water content in a membrane generally guarantees excellent proton conductivity. However, high water uptake can cause undesired side effects such as low mechanical strength, poor hydrolytic stability, low dimensional stability, and high methanol permeability, especially in DMFC applications (Kim et al., 2006). The membrane swelling (SW) is determined according to following equation (Eq. 6):

$\mathrm{SW}(\%)=\frac{\mathrm{L}_{\mathrm{wet}}-\mathrm{L}_{\mathrm{dry}}}{L_{d r y}} \times 100$

where $L_{w e t}$ and $L_{d r y}$ are the thicknesses of the wet and dry membranes, respectively. The membrane water content parameter $(\lambda)$ is the ratio of the mole number of water molecules to the sulfonate groups, and is calculated using the following equation (Eq.7):

$\lambda=\frac{\mathrm{WU}}{I E C \times M_{\text {water }}}$

where WU, IEC, and $\mathrm{M}_{\text {water }}$ are the water uptake, ion exchange capacity, and molecular weight of water $\left(18 \mathrm{~g} \mathrm{~mol}^{-1}\right)$, respectively.

\subsection{Ion exchange capacity measurement}

The ion exchange capacity (IEC) indicates the number of milliequivalents of ions in $1 \mathrm{~g}$ of the dry polymer (Smitha et al., 2003). IEC of membranes is measured with the back-titration method. Membranes in acid form are immersed in a sodium chloride $(\mathrm{NaCl})$ solution for about 24 $\mathrm{h}$ to replace $\mathrm{H}^{+}$ions with $\mathrm{Na}^{+}$ions. Then, the released $\mathrm{H}^{+}$is titrated with sodium hydroxide $(\mathrm{NaOH})$ using phenolphthalein as indicator. The IEC value is calculated by using Equation 8:

$I E C=\frac{V_{\mathrm{NaOH}}-C_{\mathrm{NaOH}}}{W_{\text {dry }}}$

where $\mathrm{V}_{\mathrm{NaOH}}$ is the $\mathrm{NaOH}$ solution volume used to neutralize $(\mathrm{ml})$ the $\mathrm{H}^{+}, \mathrm{C}_{\mathrm{NaOH}}$ is the concentration of $\mathrm{NaOH}\left(\mathrm{mol} \mathrm{L}^{-1}\right)$ and $\mathrm{W}_{\mathrm{dry}}$ is the mass of the dry membrane $(\mathrm{g})$.

\subsection{Durability/stability}

\subsubsection{Oxidative stability}

The $\mathrm{H}_{2} \mathrm{O}_{2}$ generation at the cathode (due to the electrochemical twoelectron reduction of oxygen) and at the anode (due to the chemical combination of crossover oxygen and hydrogen) and its decomposition to intermediate products, such as $\mathrm{HO}^{\circ}$ and $\mathrm{HO}_{2}{ }^{\circ}$, could cause membrane chemical/electrochemical degradation (Bose et al., 2011). The oxidative stability of membranes is investigated by immersing of a membrane sample in Fenton's reagent ( 3 wt. $\% \mathrm{H}_{2} \mathrm{O}_{2}+2$ ppm $\mathrm{FeSO}_{4}$ ) in a shaking bath at $80{ }^{\circ} \mathrm{C}$. The oxidative stability is evaluated in terms of the weight loss of the membranes when they start to break into pieces (due to the attack of radical species; $\mathrm{HO}^{\circ}$ and $\mathrm{HOO}^{\circ}$ ) for an elapsed time (Amirinejad et al., 2011)

\subsubsection{Thermal stability}

Thermal decomposition of membranes is investigated by using thermogravimetric analyzer (TGA). The decomposition profiles of membranes measured by TGA depend on many factors, including heating rate, gas (nitrogen or oxygen) flow rate, and sample preparation technique (Mishra et al., 2012). There are generally three stages in the decomposition process of membranes: (1) the release of free and bound water molecules; (2) the decomposition of functional groups; and (3) the separation of core series of the membrane (Zakaria et al., 2016). Meanwhile, thermal transition behaviour (glass transition) of PEMs is obtained by differential scanning calorimetry (DSC) study (Tripathi and Shahi, 2011). 


\subsubsection{Mechanical stability}

In view of the potential practical applications in lithium batteries, fuel cells, electrochromic windows, and other electrochemical devices, it is essential for polymer electrolyte membranes to retain good mechanical strength (Wang and Kim, 2007). The membrane must have good mechanical resistance to stretching and shear in hydrated and dry states (Laberty-Robert et al., 2011). Dynamical mechanical analysis (DMA) technique has been used to determine mechanical stability of membranes. Briefly, samples are submitted to a periodic mechanical strain or stress, while the temperature is changed with a constant rate. The storage modulus E' (elastic) and loss modulus E" (viscous) of polymers are measured as a function of temperature. The E"/E' ratio, also named $\tan \delta$, is related to mechanical damping (Sgreccia et al., 2010).

\section{Hybrid organic-inorganic membranes (nanocomposite membranes)}

Inorganic-organic composite membranes can be classified into two main categories: 1) membranes composed of proton conductive polymers and lessproton conductive inorganic particles and 2) membranes composed of proton conductive particles and less-proton conductive organic polymers (Zhang et al., 2012). Incorporation of inorganic nanoparticles into a polymer matrix strongly influence the original characteristic of the polymers, due to the interface interaction with the polymer matrix. The inclusion of inorganic fillers improves the mechanical properties and the membrane water management, while also suppresses fuel crossover by increasing the transport pathway tortuousness (Peighambardoust et al., 2010). The preparation method of composite membranes containing inorganic and inorgano-organic protonconducting particles is very important as it will influence the microstructure of the membrane. The intrinsic characteristics of the particles such as size or the specific surface area, type, surface acidity, shape, and their interactions with the polymer matrix are particularly important and can induce large variations in membrane performance (Laberty-Robert et al., 2011). However, enrichment of the available fillers, especially nano-sized fillers, has been one of the most investigated subjects ( $\mathrm{Li}$ et al., 2013). The fillers can be classified into two types, 1) solid nonporous filler, such as $\mathrm{SiO}_{2}$, and $\mathrm{TiO}_{2}$ nanoparticles, and 2) solid porous filler, such as Zeolites, porous metal oxides, metalorganic frameworks (MOFs), and carbon nanotubes (CNT). Countless organic-inorganic hybrid nanocomposite membranes have been reported in the literature by using inorganic material such as: silicates, titanium dioxide, zirconium dioxide, iron oxide, yttrium oxide, zirconium phosphate, heteropolyacids, and CNT. The nanocomposite membranes based on different fillers will be described in the following sections.

\subsection{Nanocomposite PEMs with graphene oxide}

Graphene oxide (GO) is an amphiphilic material with a two-dimensional laminated structure and contains epoxy and hydroxyl groups on the basal plane, and carboxylic acid groups along the sheet edge. The presence of these oxygen-containing functional groups facilitate the hydration of GO and helps to hold more water and improve the proton conductivity. Owing to this feature and also large surface area, as well as intrinsic mechanical (due to large Young's modulus) and chemical stability and fuel crossover barrier, GO is one of the best nanofillers to be used in PEMFCs (Chien et al., 2013; Bayer et al., 2014; Lue et al., 2015).

Beydaghi et al. (2015) prepared the nanocomposite blend membranes based on SPEEK/PVA blend polymers and $\mathrm{SGO} / \mathrm{Fe}_{3} \mathrm{O}_{4}$ nanosheets using solution casting method for DMFC applications. The methanol permeability of SPEEK/PVA blend membrane decreased from $1.78 \times 10^{-6} \mathrm{~cm}^{2} \mathrm{~s}^{-1}$ to $8.83 \times$ $10^{-7} \mathrm{~cm}^{2} \mathrm{~s}^{-1}$ with the addition of $5 \mathrm{wt} \% \mathrm{SGO} / \mathrm{Fe}_{3} \mathrm{O}_{4}$ nanosheets due to the fuel barrier properties of graphene-based nanosheets. Moreover, the proton conductivity $\left(0.084 \mathrm{~S} \mathrm{~cm}^{-1}\right.$ at $\left.25^{\circ} \mathrm{C}\right)$ of the nanocomposite membranes increased due to the interactions between the sulfonic acid groups of SGO, and the surface hydroxyl groups of $\mathrm{Fe}_{3} \mathrm{O}_{4}$ nanoparticles with free water molecules by Grotthus and Vehicle mechanism, respectively.

In a study, Kumar et al. (2014) synthesized an SGO/SPEEK composite membrane, and the effects of SGO on the properties of SPEEK such as proton conductivity and fuel cell performance were studied. The composite membranes developed exhibited a very good conductivity $\left(0.055 \mathrm{~S} \mathrm{~cm}^{-1}\right.$ at 80
${ }^{\circ} \mathrm{C}$ and $\left.30 \% \mathrm{RH}\right)$ and reasonable PEMFC performance $\left(378 \mathrm{~mW} \mathrm{~cm}^{-2}\right.$ at $80{ }^{\circ} \mathrm{C}$ and $\left.30 \% \mathrm{RH}\right)$, which were higher than that of recast SPEEK.

Among the extensive efforts devoted to the development of PEM with adequate conductivity operating under elevated temperatures and anhydrous (low humidity) conditions, acid-base composites have attracted a great deal of attention owing to their unique transport manner. Within these composites, proton donor (acid group) and acceptor (base group) are closely linked, and protons can transport between donor and acceptor via the Grotthuss mechanism without water.

An acid-base-paired nanocomposite membranes was fabricated by $\mathrm{He}$ et al. (2014), using polydopamine-modified GO into SPEEK matrix Nanocomposite membrane with $10 \mathrm{wt} . \%$ of fillers displayed an anhydrous proton conductivity of $0.498 \mathrm{mS} \mathrm{cm}^{-1}$ in comparison with SPEEK control membrane $\left(0.387 \mathrm{mS} \mathrm{cm}^{-1}\right)$. This study showed a $47 \%$ increase in maximum current density $(698.6 \mathrm{~mA} \mathrm{~cm}-2)$ coupled with a $38 \%$ increase in maximum power density $\left(192.1 \mathrm{~mW} \mathrm{~cm}^{-2}\right)$ with $5 \mathrm{wt} . \%$ fillers.

Zarrin et al. (2011) also investigated the effects of functionalized GO with 3-mercaptopropyltrimethoxysilane (MPTMS) and subsequen oxidation of the thiol groups to sulfonic acid groups, as inorganic fillers in a Nafion ${ }^{\circledR}$ composite membrane for high temperature PEMFCs. Proton conductivity and single cell test results exhibited significant improvements for functionalized GO/Nafion ${ }^{\circledR}$ membranes (4 times) over recast Nafion ${ }^{\circledR}$ at $120{ }^{\circ} \mathrm{C}$ with $25 \%$ humidity. In a recent study, He et al. (2016) fabricated Nafion ${ }^{\circledR} / \mathrm{GO}$ composite membranes via spin-coating method using 1,4-phenylenediamine-2-sulfonic acid (PDASA) as crosslinker (see Figure 5). The authors claimed that methanol permeability decreased by $93 \%$ while retaining the high proton conductivity of Nafion ${ }^{\circledR}$, due to the synergistic optimization of methanoltransport and proton-transport channels within the GO film.

The layer-by-layer (LBL) self-assembly is a simple and remarkably adaptable method introduced by Decher (1997) and Decher et al. (1998), and has been applied to deposit a thin multilayer film on a substrate by electrostatic association between alternately deposited, oppositely charged components. LBL technology has been used successfully in the area of both PEMs and DMFC electrodes and electrolytes (Kim et al., 2004; Farhat and Hammond, 2006; Jiang et al., 2006).

Recently, Nafion ${ }^{\circledR} / \mathrm{GO}$ composite membranes was fabricated via the LBL procedure using 1,4-phenyldiamine hydrochloride (PDHC) as crosslinker and was used as a PEM for DMFC (Wang et al., 2015). The composite membranes exhibited higher selectivity and lower methanol permeability than Nafion ${ }^{\circledR} 117$. Yuan et al. (2014) also demonstrated that the GO multilayer films on the Nafion ${ }^{\circledR}$ membranes not only reduced methanol crossover by $67 \%$ but also enhanced membrane strength. In their work, poly (diallyldimethylammoniumchloride) (PDDA) was used as cross-linker.

\subsection{Nanocomposite PEMs with heteropolyacids}

Polyoxometalates (POMs) are Brønsted acids with nano-size metaloxygen clusters which have received much attention in recent years owing to their thermal stability and intrinsic proton conductivity $\left(0.18 \mathrm{~S} \mathrm{~cm}^{-1}\right.$ in the hydrated crystalline form (phosphotungstic acid; PTA.29 $\mathrm{H}_{2} \mathrm{O}$ )) (Malers et al., 2007). POMs incorporation in the polymer matrix enhance the proton conductivity and the FC performance due to hygroscopic properties and strong acid strength of POMs cluster compounds by providing a preferential pathway for proton hopping and sustaining a large number of water molecules in their hydration sphere. However, the major obstacle faced in the utilization of POMs in PEMs is their high solubility in water and the low surface area of PTA $\left((5-8) \mathrm{m}^{2} \mathrm{~g}^{-1}\right)$ which limits the accessibility to acid sites (Kourasi et al., 2014). In order to increase the stability and the surface area, two approaches have been suggested. The first involves fixation of the POMs on support oxides such as $\mathrm{SiO}_{2}, \mathrm{Al}_{2} \mathrm{O}_{3}$, $\mathrm{ZrO}_{2}$, and $\mathrm{TiO}_{2}$ (Saccà et al., 2008). The second option is the use of heteropoly salts by substituting the protons $\left(\mathrm{H}^{+}\right)$with large cations such as $\mathrm{Cs}^{+}, \mathrm{NH}^{+}, \mathrm{Rb}^{+}$and $\mathrm{Tl}^{+}$(Ramani et al., 2005b). This second approach was investigated by Amirinejad et al. (2012). They dispersed $\mathrm{Cs}_{2.5} \mathrm{H}_{0.5} \mathrm{PW}_{12} \mathrm{O}_{40}$ (CsPW) and $\mathrm{H}_{3} \mathrm{PW}_{12} \mathrm{O}_{40} / \mathrm{SiO}_{2}$ (PWS) throughout the sulfonated fluorinated bi-phenol (ESF-BP) copolymer separately and the performances of the fabricated membranes were investigated. Both POMs used provided additional surface functional sites throughout the composite 

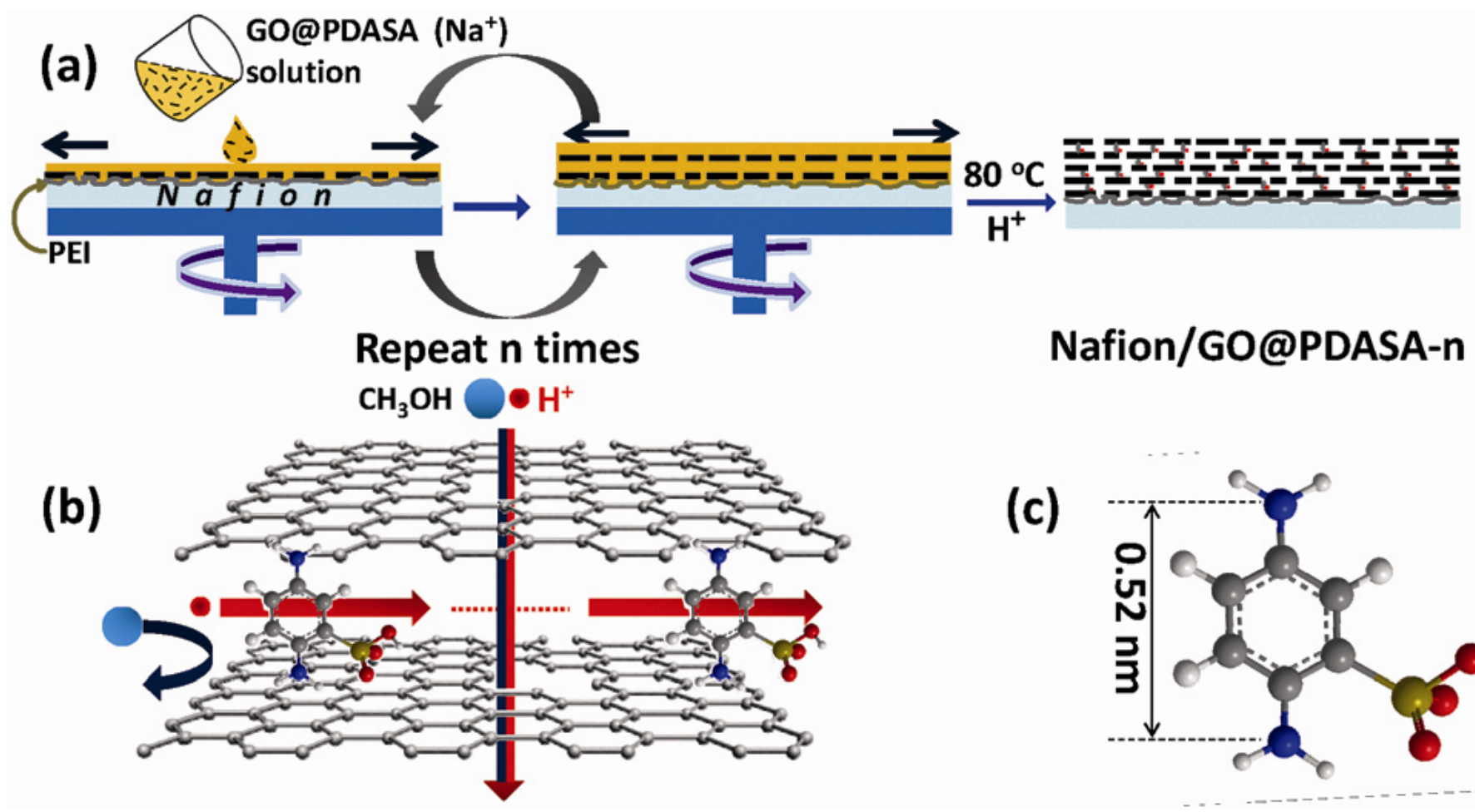

(c)

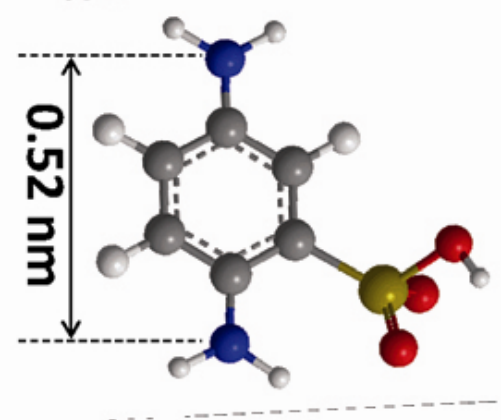

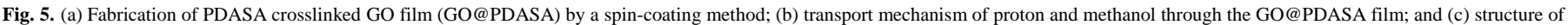
1, 4-phenylenediamine-2-sulfonic acid (PDASA) (He et al., 2016). Copyright (2016), reprinted with permission from RSC.

membranes and facilitated proton transport. However, the conductivity and consequently the performance of the ESF-BP/7PWS membrane was reportedly higher than that of the ESF-BP/7CsPW membrane due to the higher number of acid sites and surface area.

Kim et al. (2015b) also studied polymer electrolyte FCs operating at elevated temperatures and low RH by utilizing a polyoxometalate modified GO-Nafion ${ }^{\circledR}$ membrane. The Nafion ${ }^{\circledast} / \mathrm{PW}$-mGO membrane exhibited a proton conductivity and a maximum power density of $10.4 \mathrm{mS} \mathrm{cm}^{-1}$ and 841 $\mathrm{mW} \mathrm{cm}{ }^{-2}$ at $20 \% \mathrm{RH}$ at $80^{\circ} \mathrm{C}$, respectively.

In a similar attempt, water uptake, proton conductivity, and $\mathrm{FC}$ performance of Nafion ${ }^{\circledR}$ membrane was increased by the incorporation of $\mathrm{SiO}_{2}$-PTA (Mahreni et al., 2009). The $\mathrm{Nafion}^{\circledR} / \mathrm{SiO}_{2} / \mathrm{PTA}$ composite membrane exhibited a current density of $82 \mathrm{~mA} \mathrm{~cm}^{-2}$ at $0.6 \mathrm{~V}$ as compared with the Nafion ${ }^{\otimes}$ membrane $(30 \mathrm{~mA} \mathrm{~cm}$ at $0.2 \mathrm{~V})$. Recently, HasaniSadrabadi et al. (2016) reported modified Nafion ${ }^{\circledR}$ membranes with PTAfilled CNT nanostructures. The fabricated Nafion ${ }^{\circledR} /$ nanopeapod membranes demonstrated a proton conductivity and a power density of $0.202 \mathrm{~S} \mathrm{~cm}^{-1}$ (at $90{ }^{\circ} \mathrm{C}$ ) and $302 \mathrm{~mW} \mathrm{~cm}^{-2}$ (at $40 \% \mathrm{RH}$ and $120{ }^{\circ} \mathrm{C}$ ), respectively, in comparison with $0.132 \mathrm{~S} \mathrm{~cm}^{-1}$ and $84 \mathrm{~mW} \mathrm{~cm}^{-2}$ for the recast Nafion ${ }^{\circledR}$ membrane.

Zhao et al. (2009) demonstrated that the multilayer films placed onto the surface of sulfonated poly(arylene ether ketone) (SPAEK-COOH) membrane by the LBL self-assembly of polycation chitosan (CTS) and negativelycharged inorganic particle PTA reduced methanol permeability by 2 orders of magnitude compared with Nafion ${ }^{\circledR} 117$ while maintaining a high proton conductance. Figure 6 illustrates the fabrication of the (CTS/PTA) multilayer films.

\subsection{Nanocomposite PEMs with NCTs}

Among inorganic fillers, CNTs, which are cylindrical graphene tubes with a nano-sized diameter consist of single or several graphene layers, have attracted considerable attention owing to their high aspect ratios of 100-1000, high specific surface areas, low densities, and remarkable mechanical properties. Because of these unique properties, recently, CNTs have been widely investigated as candidate PEM materials. Furthermore, the properties and performances of nanotubes can be significantly intensified through coordination effects by modification with different functionalized groups such as carboxylic acid-functionalized CNTs (Thomassin et al., 2007), sulfonated CNTs (Yun et al., 2011; Zhou et al., 2011; Yu et al., 2013), phosphonated CNTs (Kannan et al., 2010; Kannan et al., 2011), and Nafion ${ }^{\circledR}$ - and polybenzimidazole functionalized CNTs (Chang et al., 2011; Hasani-Sadrabadi et al., 2013).

Recently Cui et al. (2015) reported the incorporation of silica-coated CNTs as a new additive into the SPEEK matrix for DMFC applications. The composite membranes with a $\mathrm{SiO}_{2} @ \mathrm{CNT}$ loading of 5 wt.\% showed one order of magnitude decrease in methanol crossover in comparison with pristine membranes, while the proton conductivity remained above $10-2 \mathrm{~S} \mathrm{~cm}^{-1}$ at room temperature.

Zhang et al. (2014) synthesized sulfonated halloysite nanotubes (SHNTs) via a facile distillation precipitation polymerization, and found that incorporating $10 \%$ SHNTs enhanced the conductivity of SPEEK from 0.0152 to $0.0245 \mathrm{~S} \mathrm{~cm}^{-1}$. The embedded SHNTs not only interconnected the ionic channels in SPEEK matrix and donated more continuous ionic networks which could serve as proton pathways allowing efficient proton transfer with low resistance, but also increased the thermal and mechanical stabilities of the resultant nanocomposite membranes by interfering with SPEEK chain motion and packing. 

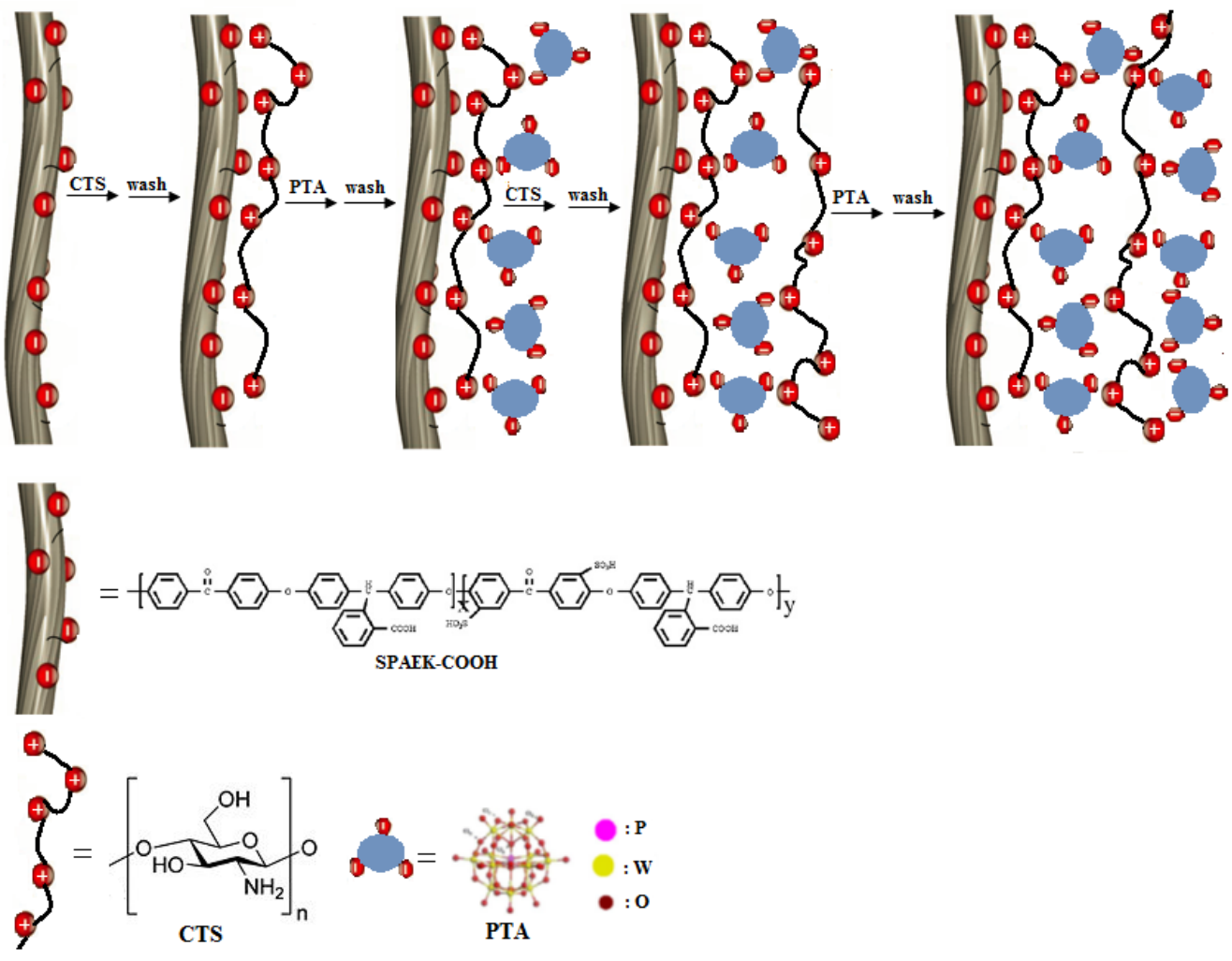

Fig. 6. Schematic representation of the fabrication of (CTS/PTA) $)_{n}$ multilayer films. Adopted from Zhao et al. (2009).

By incorporating imidazole groups on the surface of CNTs into Nafion ${ }^{\circledR}$, significant improvements in the power density, methanol permeability, and proton conductivity was achieved by Asgari et al. (2013). They investigated FC performance of the Nafion ${ }^{\circledR}$ doped with 0.5 wt.\% CNTs and Im-CNT at two different methanol concentrations, i.e., $1 \mathrm{M}$ and $5 \mathrm{M}$ at $70{ }^{\circ} \mathrm{C}$. The results obtained using the Nafion ${ }^{\circledR} / \mathrm{Im}-\mathrm{CNT}-0.5$ wt.\% showed current and power densities of 500 and $300 \mathrm{~mA} \mathrm{~cm}^{-2}$ and $86.53,74.22 \mathrm{~mW} \mathrm{~cm}^{-2}$ at 1 and $5 \mathrm{M}$ methanol, respectively. The open circuit voltage (OCV) of the Nafion ${ }^{\circledR} / \mathrm{Im}$ CNT-0.5 wt.\% membranes was found higher than those of the other membranes. i.e., recast Nafion ${ }^{\circledR}$ and Nafion ${ }^{\circledR} / \mathrm{CNT}-0.5$ wt. $\%$. This could be ascribed to the strong interactions between imidazole groups and Nafion ${ }^{\circledR}$ molecules which in turn decreased the size of channels and subsequently notably hindered methanol diffusion. Yun et al. (2011 and 2012) developed a sulfonated multi-walled CNT/sulfonated PES (s-MWCNT-s-PES) and sulfonated PVA/sulfonated multi-walled CNT (s-MWNTs/s-PVA) nanocomposite membranes. In both of these studies, s-MWCNT was added in order to act as filler for DMFC. The composite membranes demonstrated excellent proton conductivity and low methanol permeability.

\subsection{Nanocomposite PEMs with $\mathrm{SiO}_{2}$}

Silicate-based nanoparticles have been extensively studied because of their lower cost, inferior electrical conductivity, and better water retention properties compared with those of the other nanoparticles. By modifying the silicate surface using different modifiers phase inconsistency between organic polymer membranes and inorganic silicate could be avoided. In general, silica is synthesized through the hydrolysis and polycondensation of alkoxy silanes in an acidic or basic medium, using different precursors such as alkoxy silanes (like tetraethyl orthosilicate (TEOS)), sodium metasilicate, and fumed silica (Mishra et al., 2012). The hydrophilic nature of silicates helps in developing the proton conductivity of nanocomposite membranes. Moreover, addition of sulfonated and phosphonated silicates along with a high degree of dispersion of the nanomaterials in the polymer matrix can notably upgrade the conductivity of the nanocomposites.

Yoon et al. (2009) compared the performance of sulfonated poly(arylene ether sulfone (SPAES) $/ \mathrm{SiO}_{2}$ membranes prepared by wettype milling method and sonication method. Comparatively, wet-type milling method remarkably improved the dispersion of $\mathrm{SiO}_{2}$ in the SPAES matrix, due to the intensive impact of collisions between milling beads and nanoparticles. This enhancement in nanoparticle dispersion improved proton conductivity as well as methanol permeability and selectivity in the composite membranes.

The incorporation of $\mathrm{SiO}_{2}$ nanoparticles in sulfonated polyimide containing triazole groups (SPI-8) remarkably improved the FC performances during low humidity operation at $53 \% \mathrm{RH}$ and $80{ }^{\circ} \mathrm{C}$ (Sakamoto et al., 2014). Influence of the size and shape of silica nanoparticles on the properties and degradation of PBI-based membranes was investigated by Ossiander et al. (2014). PBI-based membranes with $40 \%, 80 \%$, and $120 \%$ of the inorganic silica precursor TEOS were fabricated using in situ sol-gel reaction using (3-glycidoxypropyl)methyldiethoxysilane (GPTMS) as crosslinker. The results obtained showed higher performance and mechanical stability in the composite membranes with $40 \%$ TEOS content.

Sulfonated GO-silica $\left(\mathrm{S}-\mathrm{GO}-\mathrm{SiO}_{2}\right) / \mathrm{Nafion}^{\circledR}$ PEMs with enhanced transport properties were prepared via solution casting by Feng et al. (2014). The composite membranes showed an obvious reduction in methanol permeability (due to the increased tortuosity of the transport channels in the membrane matrix) as well as higher proton conductivity, and 2-fold increased selectivity (the ratio of proton conductivity to methanol permeability) compared with the recast Nafion ${ }^{\circledR}$ membrane. Farrukh et al. (2015) modified surface silica nanoparticles with poly(monomethoxy oligoethylene glycol methacrylate), poly(MeOEGMA), and employed them as conductivity enhancing additives for the fabrication of Nafion ${ }^{\circledR}$ nanocomposite membranes. The 
modified membranes containing $1 \%$ additives showed $\sim 11$ times higher proton conductivity at $20 \% \mathrm{RH}$ and $25{ }^{\circ} \mathrm{C}$, whereas at the same temperature and $80 \% \mathrm{RH}$, the proton conductivity of the nanocomposite membrane was $\sim 4$ times higher than that of the Nafion ${ }^{\circledR}$.

\subsection{Nanocomposite PEMs with $\mathrm{TiO}_{2}$}

$\mathrm{TiO}_{2}$ is a hygroscopic metal oxide which improves the cell performance, in terms of higher operating temperature, easier water management, and thermo mechanical stability (Bose et al., 2011). Cozzi et al. (2014) synthesized and investigated propylsulfonic functionalized titania $\left(\mathrm{TiO}_{2}-\mathrm{RSO}_{3} \mathrm{H}\right)$ as inorganic fillers in a Nafion ${ }^{\circledR}$ composite membrane. The composite membrane containing $10 \mathrm{wt} . \%$ of fillers displayed the highest conductivity value $(\sigma=$ $0.08 \mathrm{~S} \mathrm{~cm}^{-1}$ at $140{ }^{\circ} \mathrm{C}$ ) and the best DMFC performance, with $64 \mathrm{~mW} \mathrm{~cm}$ power density (about $40 \%$ higher than the Nafion ${ }^{\circledR}$ cast membrane). SPEEK/phosphonic acid-functionalized titania nanohybrid membranes were fabricated by an in situ method using titanium tetrachloride $\left(\mathrm{TiCl}_{4}\right)$ as inorganic precursor and amino trimethylene phosphonic acid (ATMP) as modifier (Wu et al., 2015). The nanohybrid membranes demonstrated remarkably enhanced proton conduction (25\%), a $23 \%$ decrement in methanol permeability, and also better thermal and mechanical stabilities. Gandhi et al. (2012) also showed that the addition of titanium dioxide had a very dramatic and positive effect on proton conductivity of pure polystyrene porous membranes. Aslan and Bozkurt (2014) synthesized proton conducting nanocomposite membranes via ternary mixtures comprising sulfated nanotitania (TS), sulfonated polysulfone (SPSU), and nitrilotri(methyl triphosphonic acid) (NMPA). These membranes displayed a maximum proton conductivity of $0.002 \mathrm{~S} \mathrm{~cm}^{-1}$ at $150^{\circ} \mathrm{C}$.

Amjadi et al. (2010) prepared $\mathrm{Nafion}^{\circledR}-\mathrm{TiO}_{2}$ nanocomposite membranes by sol-gel and casting methods. Their results revealed that sol-gel method was better than casting due to the formation of fine particles and good distribution of $\mathrm{TiO}_{2}$ particles. Water uptake (up to $3 \mathrm{wt} . \%$ ) and thermal properties of these membranes were improved with increasing $\mathrm{TiO}_{2}$ content. PEMFC performance at $110{ }^{\circ} \mathrm{C}$ was improved, in spite of a slight reduction in proton conductivity. To improve the interfacial compatibility between polymeric resin and inorganic materials and to enhance proton conductivity, Li et al. (2012) modified the Nafion ${ }^{\circledR}$ by of amine-tailored titanate nanotubes. The composite membranes developed showed about 4-5 times higher proton conductivity in comparison with pristine Nafion ${ }^{\circledR}$ and 3 times higher proton conductivity compared with that of composite membrane impregnated with unmodified titanate nanotubes. Wu et al. (2014) synthesized a series of amino acid functionalized titania submicrospheres $(\sim 200 \mathrm{~nm})$ and incorporated them into SPEEK. All the as-prepared hybrid membranes exhibited improved methanol resistance compared with pristine SPEEK membrane. This could be rationalized by the size reduction of the ionic channels, which was unfavourable for methanol crossover. Moreover, the incorporation of this filler could introduce acid-base pairs as proton donors and acceptors into polymer, which helped to form continuous pathways for proton hopping, thus leading to increased proton conductivity.

\subsection{Nanocomposite PEMs with perovskite-type oxides}

Protonic conductors with perovskite structures have been considered attractive owing to their high chemical stability, excellent thermal and mechanical stability, relatively low cost, and high applicability in electrochemical devices for energy generation (An et al., 2012). Recently, nanocomposite membranes based on perovskite-type oxides for high temperature PEMFCs have been studied by Hooshyari et al. (2015) and Shabanikia et al. (2015). Accordingly, polybenzimidazole- nanocomposite membranes based on $\mathrm{BaZrO}_{3}$ and $\mathrm{SrCeO}_{3}$ reportedly displayed higher water uptake and proton conductivity compared with virgin PBI membranes. This improvement was attributed to the hygroscopic nature of $\mathrm{BaZrO}_{3}$ and $\mathrm{SrCeO}_{3}$ nanoparticles. Also they investigated the effects of variations in the percentages of the nanoparticles and the solvent used (water, ethanol, and water/ethanol $(1: 1 \mathrm{v} / \mathrm{v}))$ for the dispersion of nanoparticles within of Nafion ${ }^{\circledR} / \mathrm{Fe}_{2} \mathrm{TiO}_{5}$ nanocomposite membranes on the proton conductivity, water uptake, and also the thermal stability of the membranes (Hooshyari et al., 2014). The results displayed that 2 wt.\% of the nanoparticles $v s$. Nafion ${ }^{\circledR}$ membrane in $10 \mathrm{~mL}$ water as solvent had the highest proton conductivity (226 $\pm 7 \mathrm{mS} \mathrm{cm}^{-1}$ ) compared with the other membranes at $25^{\circ} \mathrm{C}$ and $95 \% \mathrm{RH}$ due to the existence of water as more polar solvent and large affinity of the $\mathrm{Fe}_{2} \mathrm{TiO}_{5}$ nanoparticles with water.

\subsection{Nanocomposite PEMs with zeolite}

Zeolites are a class of crystalline aluminosilicates, which form a framework of $\mathrm{SiO}_{2}$ and $\mathrm{AlO}_{4}$ tetrahedra and contain exchangeable cations on the extra-framework to maintain the electrical neutrality (Dyer, 1988). Zeolites are highly hydrophilic solids and have a high water sorption capacity because of the charged anionic framework and the extraframework cations (Kornatowski, 2005; Ng and Mintova, 2008) in addition to their open structure, high pore volume, and vast surface area. Most zeolites reportedly used in the composite membranes for FCs are micrometer-sized particles with low proton conductivity (Libby et al., 2003; Tricoli and Nannetti, 2003). Nanometer-sized inorganic additives have been proven to be crucial to the compatibility between the inorganic filler and Nafion ${ }^{\circledR}$, which has significant effects on the proton conductivity and methanol permeability of the composite membranes (Zimmerman et al., 1997). Different types of zeolite nanocrystals (A, $\mathrm{NaX}, \mathrm{NaY}, \mathrm{Beta}$, etc.) have been prepared successfully by template and template-free methods (Wang et al., 2002; Wang et al., 2003; Chen et al., 2005; Holmberg et al., 2005). To minimize the loss of proton conductivity caused by the fillers while reducing the methanol permeability, acid functionalized $\left(-\mathrm{SO}_{3} \mathrm{H}\right)$ zeolites have been prepared (Jones et al., 1998) and used successfully as an inorganic filler in composite membranes (Holmberg et al., 2005). The acid functionalized zeolites were selected for their favourable proton conductivity $\left(\sim 0.02 \mathrm{~S} \mathrm{~cm}^{-1}\right)$, excellent acid stability, and hydrophilic nature.

Recently, Devrim and Albostan (2015) modified Nafion ${ }^{\circledR}$ membranes with zeolit by solvent casting procedure; the modified membranes demonstrated increasing water uptake and proton conductivity owing to the water retention properties of the zeolite and interaction between the Nafion ${ }^{\circledR}$ polymer and zeolite particles. In another study, Auimviriyavat et al. (2011) reported ferrierite zeolite as inorganic filler in SPEEK membrane. In general, ferrierite zeolite in known to possess favourable acid and thermal stabilities because of its relatively high $\mathrm{SiO}_{2} / \mathrm{Al}_{2} \mathrm{O}_{3}$ molar ratio (Gögebakan et al., 2007). Auimviriyavat et al. (2011) claimed that ferrierite zeolite improved the mechanical strength and water retention of the membrane. These membranes demonstrated better proton conductivity, low methanol permeability, and the highest selectivity of $7.148 \times 10^{-3} \mathrm{~S}$. $\mathrm{cm} \mathrm{s}^{-1}$. Nafion ${ }^{\circledR} /$ acid functionalized zeolite beta (NAFB) nanocomposite membranes were also prepared via in situ hydrothermal crystallization by Chen et al. (2006), with showed a slightly lower proton conductivity but a markedly lower methanol permeability (40\% less) in comparison with Nafion ${ }^{\circledR}$ membranes (Fig. 7). These membranes were also shown to offer higher OCV (by 3\%) and higher maximum power density (by $21 \%$ ) than Nafion ${ }^{\circledR}$.
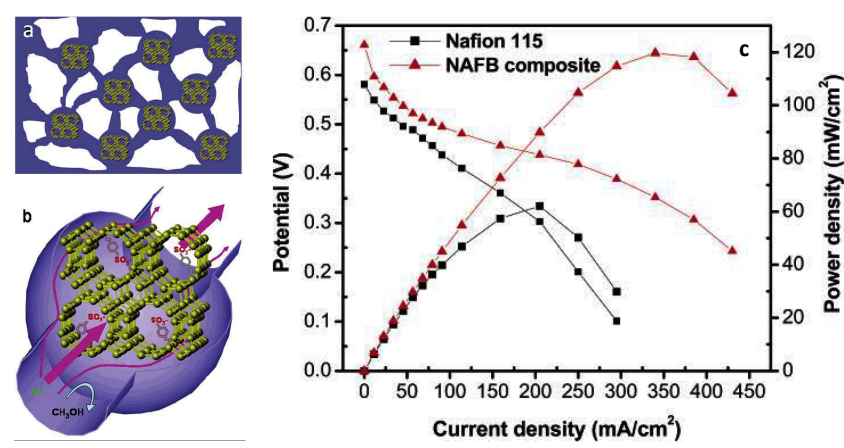

Fig. 7. Schematics of NAFB composite membrane and its proton and methanol transport: a) white region represents the hydrophobic section of the Nafion ${ }^{\circledast}$ membrane and the coloured region represents the hydrophilic section of the Nafion ${ }^{\circledR}$ membrane; b) proton and methanol transport in the NAFB composite membrane; and (c) DMFC single cell performance at $70{ }^{\circ} \mathrm{C}$, fed with $5 \mathrm{M}$ methanol (Chen et al., 2006). Copyright (2016), reprinted with permission from ACS. 


\subsection{Nanocomposite PEMs with iron oxide}

Iron oxide nanoparticles have received a great deal of attention owing to their easy and controlled synthesis, low toxicity, magnetic and catalytic properties, and as a result, their potential applications in different fields such as magnetic resonance imaging (MRI) (Sun et al., 2008), drug targeting (Chomoucka et al., 2010), catalysts (Maleki et al., 2014; Safari and Javadian, 2014), and hyperthermia treatments (Laurent et al., 2011). The fabrication of anisotropic membranes orientated in the desired direction in a matrix is an attractive idea to enhance ionic conductivity. Two methods to design anisotropic nanocomposite membranes are to align nanofillers in the matrix under electric field (Oren et al., 2004) or magnetic field (Brijmohan and Shaw, 2007). In a study, $\mathrm{SGO} / \mathrm{Fe}_{3} \mathrm{O}_{4}$ nanosheets were aligned under magnetic field in PVP matrix by Beydaghi and Javanbakht (2015). With the orientation of the $\mathrm{SGO} / \mathrm{Fe}_{3} \mathrm{O}_{4}$ nanosheets, the water transferring channels in the membrane became wide and the empty spaces accommodating water molecules in the membranes increased, hence, water uptake and swelling of membranes increased. Moreover, these membranes showed higher thermal stability, methanol permeability, and selectivity with a maximum power density of $25.57 \mathrm{~mW} \mathrm{~cm}{ }^{-1}$ at $30{ }^{\circ} \mathrm{C}$ compared with a nonaligned membrane (Beydaghi and Javanbakht, 2015). Hasani-Sadrabadi et al. (2014a) aligned CTS-coated superparamagnetic iron oxide nanoparticles (CTS-SPIONs) in Nafion ${ }^{\circledR}$ matrix. Figure 8 presents a cross section of a high resolution transmission electron microscopy (HR-TEM) image of the aligned nanocomposite which clearly confirms a chain-like assembly of the CTSSPIONs because of the magnetic field (Hasani-Sadrabadi et al., 2014a). The modified membranes displayed a power output over five times higher than that of the unmodified Nafion ${ }^{\circledR}$ at $120{ }^{\circ} \mathrm{C}$ and $40 \% \mathrm{RH}$. In an investigation, the surface of $\gamma-\mathrm{Fe}_{2} \mathrm{O}_{3}$ nanoparticles was modified by MPTMS as sulfonic acid functional group precursor and subsequently, a magnetic field was applied during solvent casting and evaporation to align the nanoparticles in Nafion matrix (Hasanabadi et al., 2013). The aligned nanocomposite membranes showed higher ionic conduction, drastic reduction in methanol permeability and activation energy for proton migration, and also significant higher selectivity as compared with randomly-distributed nanocomposite membranes.

\subsection{Nanocomposite PEMs with MOFs}

MOFs, or coordination polymers (CPs), are open networks consisting of metal-centered secondary building units (SBUs) joined together by organic linkers to form large one-dimensional (1-D), two-dimensional (2D), or three-dimensional (3-D) networks (Ren et al., 2013). Structural features of MOFs such as their crystallinity, regular arrangement of voids, tailorable porosity, and dynamic behaviour are especially attractive for their use as proton conductors (Ramaswamy et al., 2014). MOFs exhibit proton conductivity; protons can be passed through the coordination skeleton of a MOF (Ohkoshi et al., 2010) or through carriers, such as imidazole (Bureekaew et al., 2009), 1, 2, 4-triazole (Hurd et al., 2009), or water (Duan et al., 2009), loaded in the pores. Liang et al. (2013) incorporated a 2-D MOF containing protonated tertiary amines as proton carriers into a polyvinyl pyrrolidone (PVP) matrix. Conductivity measurements at $53 \% \mathrm{RH}$ and $333 \mathrm{~K}$ indicated that the conductivity increased from $1.4 \times 10^{-8}$ (for pure PVP) to $3.2 \times 10^{-4} \mathrm{~S} \mathrm{~cm}^{-1}$ for MOFPVP composite. Wu et al. (2013) reported the fabrication and characterization of a composite membrane with a high proton conductivity by combining sulfonated PPO with Fe-MIL-101- $\mathrm{NH}_{2}$ or $\left[\mathrm{Fe}_{3}(\mathrm{O})(\mathrm{BDC}-\right.$ $\left.\left.\mathrm{NH}_{2}\right)_{3}(\mathrm{OH})\left(\mathrm{H}_{2} \mathrm{O}\right)_{2}\right] \cdot \mathrm{nH}_{2} \mathrm{O}$ (where $\mathrm{BDC}-\mathrm{NH}_{2}$ is 2-aminoterephthalate) via the Hinsberg reaction, wherein a sulfonyl chloride reacts with an amine to form a sulfonamide salt (see Fig. 9).

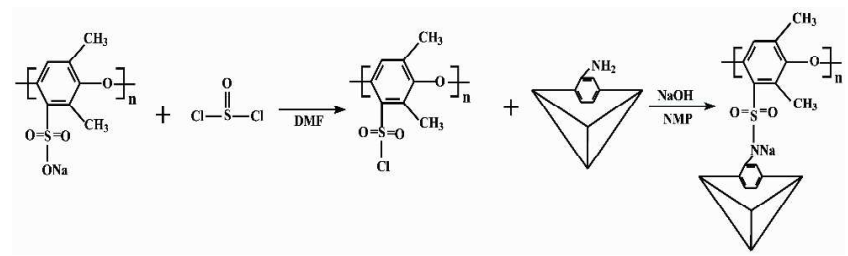

Fig. 9. The synthetic procedure of MOFs-PPO- $\mathrm{SO}_{2} \mathrm{Cl}$ membranes (Wu et al., 2013) Copyright (2016), reprinted with permission from RSC. a)

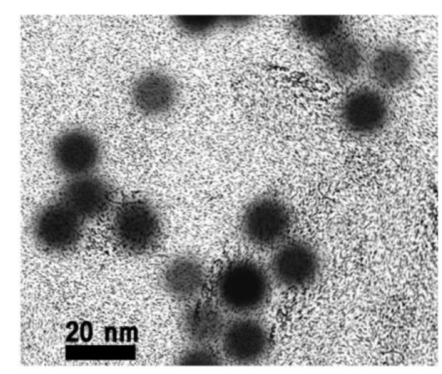

b)

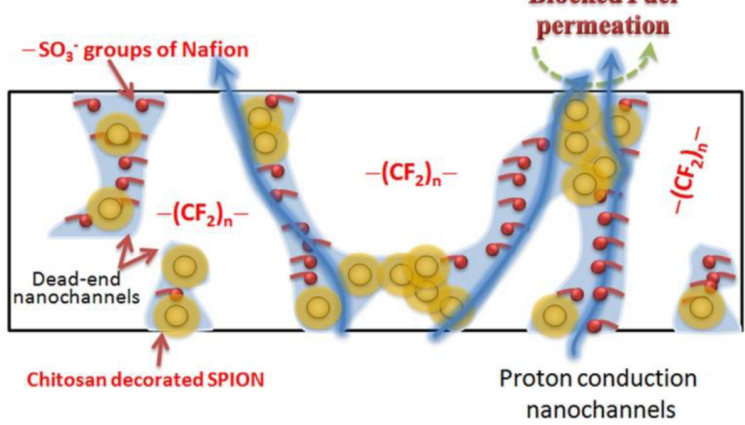

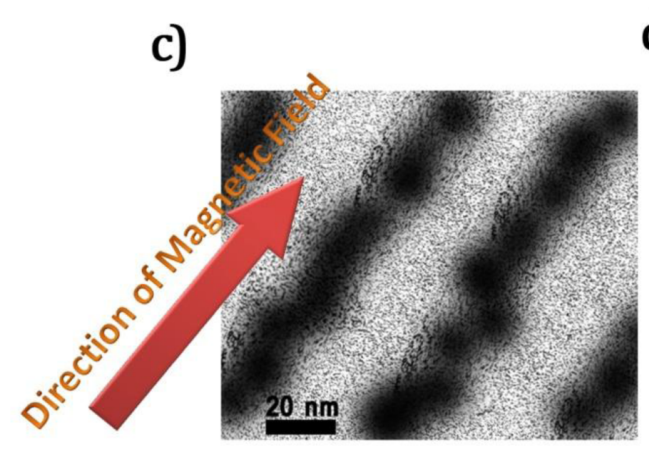

d)

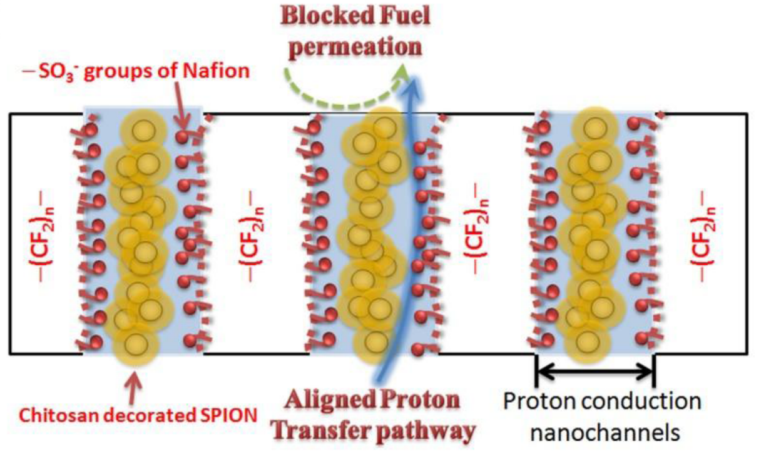

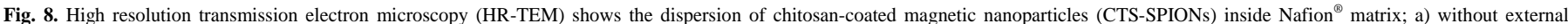

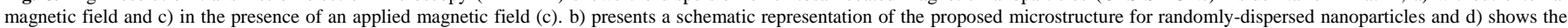
unidirectional orientation of ion conduction nanochannels (Hasani-Sadrabadi et al., 2014a). Copyright (2016), reprinted with permission from ACS. 
They claimed that the proton conductivity of the membranes was as high as $0.10 \mathrm{~S} \mathrm{~cm}^{-1}$ at room temperature and $0.25 \mathrm{~S} \mathrm{~cm}^{-1}$ at $90^{\circ} \mathrm{C}$.

Recently, a novel ternary composite membrane consisting of PVA, poly(2acrylamido-2-methylpropane sulfonic acid) (PAMPS), and zeolitic imidazolate framework-8 (ZIF-8), was prepared by physical blending and casting methods (Erkartal et al., 2016). This study showed that ZIF-8 nanoparticles $(40-60 \mathrm{~nm})$ not only assisted with the water management because of their hydrophobic nature, but also contributed to the proton conductivity by forming hydrogen bonds with the polymer network. These membranes displayed $0.134 \mathrm{~S} \mathrm{~cm}^{-1}$ proton conductivity under fully hydrated state at $80^{\circ} \mathrm{C}$.

In another study, novel Nafion ${ }^{\circledR}$-based composite membranes (PEM-1 and PEM-2) using two 1-D channel microporous MOFs as fillers; i.e., CPO$27(\mathrm{Mg})$ and MIL-53(Al) were investigated for PEMFC applications (Tsai et al., 2014). The results obtained showed improved water uptake and proton conductivity by 1.7 times and 2.1 times in magnitude, respectively, as compared with the recast $\mathrm{Nafion}^{\circledR}$ membrane. CPO-27(Mg)-Nafion composite membrane exhibited maximum power density values of $818 \mathrm{~mW} \mathrm{~cm}^{-2}$ and $591 \mathrm{~mW} \mathrm{~cm}^{-2}$, at $50^{\circ} \mathrm{C}$ and $80^{\circ} \mathrm{C}$, respectively.

Enhanced proton conductivity by sulfonated MIL101(Cr) into SPEEK matrix was also reported by Li et al. (2014). In general, MOFs, with low cost and various properties, can act as electrolytes, electrode catalysts, and catalyst precursors by adjusting the structures to obtain the optimized materials for FCs (Li and Xu, 2013).

\subsection{Nanocomposite PEMs with layered silicate materials}

Clay (layered silicates), including montmorillonite and laponite, are one class of the most widely used inorganic fillers for the preparation of polymerclay nanocomposite membranes for PEMFCs owing to high aspect ratio and excellent barrier properties (Mishra et al., 2012). The thickness of the layer is generally around $1 \mathrm{~nm}$, and the lateral dimensions of these layers vary from $30 \mathrm{~nm}$ to several $\mu \mathrm{m}$ or larger depending on the particular layered silicate (Laberty-Robert et al., 2011). In order to improve the compatibility between the inorganic clay and the organic polymer, the surfaces of the nanoclays are modified via ionic (using alkyl ammonium ions), covalent (using alkoxy
(1)

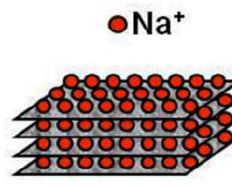

SWy

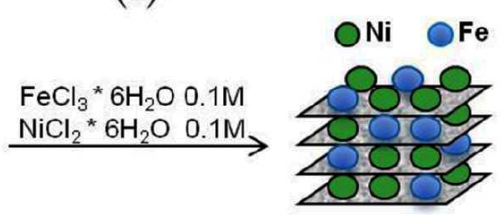

Ni-Fe-SWy

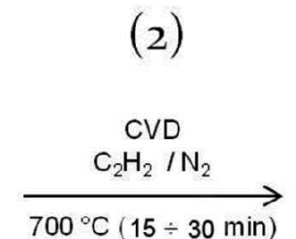

$700^{\circ} \mathrm{C}(15 \div 30 \mathrm{~min})$ , or plasma (using modifiers containing vinyl groups) modification techniques (Yen et al., 2006; Zhang, 2007; Buquet et al., 2010). The monovalent ions located between the clay layers are used for the modification allowing the absorption of polar solvents such as water (Kim et al., 2015a). Recently, organo-functionalization of CNT was grafted on smectite clays (SWy) by catalytic chemical vapour deposition (CCVD) method (Simari et al., 2016) (Fig. 10), and their composite membranes with Nafion ${ }^{\circledR}$ matrix exhibited $7 \times 10^{-2} \mathrm{~S} \mathrm{~cm}^{-1}$ proton conductivity at 120 ${ }^{\circ} \mathrm{C}$ and $30 \% \mathrm{RH}$. Bentonite clay was also modified by grafting the organo sulfonic acid groups on the surface through silane condensation, and was subsequently dispersed in SPEEK to form a composite electrolyte for its use in DMFCs (Sasikala et al., 2014). The composite membranes showed $140 \mathrm{~mW} \mathrm{~cm}{ }^{-2}$ power density in comparison with $71 \mathrm{~mW} \mathrm{~cm}^{-2}$ for pristine SPEEK membrane at $70{ }^{\circ} \mathrm{C}$ as well as high proton conduction and methanol restricting behaviour. Jana et al. (2015) prepared Poly(vinylidene fluoride) nanohybrid with organically modified 2-D layered silicate. Nanohybrids were functionalized by sulfonation using chlorosulfonic acid under controlled condition to fabricate FC membranes. Power density of the sulfonated nanohybrid membrane exhibited significantly higher value of $33 \mathrm{~mW} \mathrm{~cm}^{-2}$, against the value of $11 \mathrm{~mW} \mathrm{~cm}^{-2}$ measured for standard Nafion ${ }^{\circledR}$ at similar current density. $\mathrm{He}$ et al. (2015) investigated the effects of three types of clays; i.e., sodium montmorillonite (IC), hydrophobic organo-clay with long alkyl chains (OC), and organo-clay with carboxylic acid end groups (HC), on the structure and properties of SPEEK/clay nanocomposites. They found that the SPEEK/HC hybrid membranes achieved the best clay dispersion, higher proton conductivity (due to the interaction between the carboxylic acid groups in $\mathrm{HC}$ and sulfonic acid groups in SPEEK) and selectivity at low filler loading $(<10 \mathrm{wt} . \%)$.

In a study, a Nafion ${ }^{\circledR}$ nanocomposite membrane, with 2 wt.\% CTSfunctionalized montmorillonite was prepared via a solvent casting method and indicated surprisingly 23 -times higher membrane selectivity (HasaniSadrabadi et al., 2010).

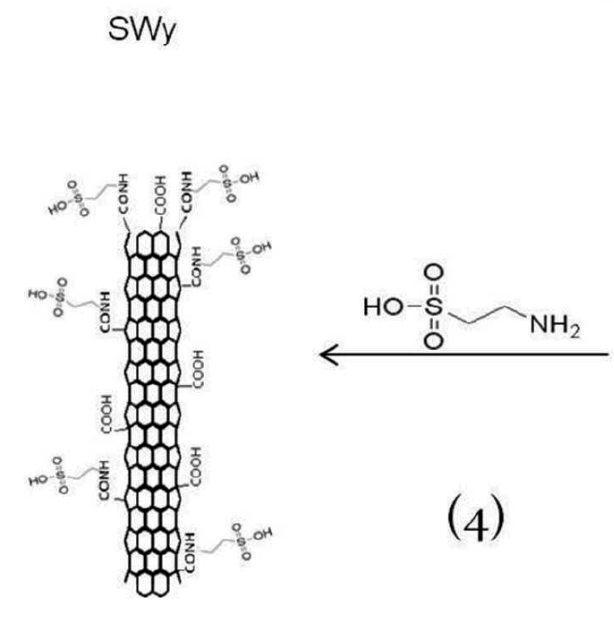

SWy-oxCNTs-RSO $\mathrm{SH}_{3}$
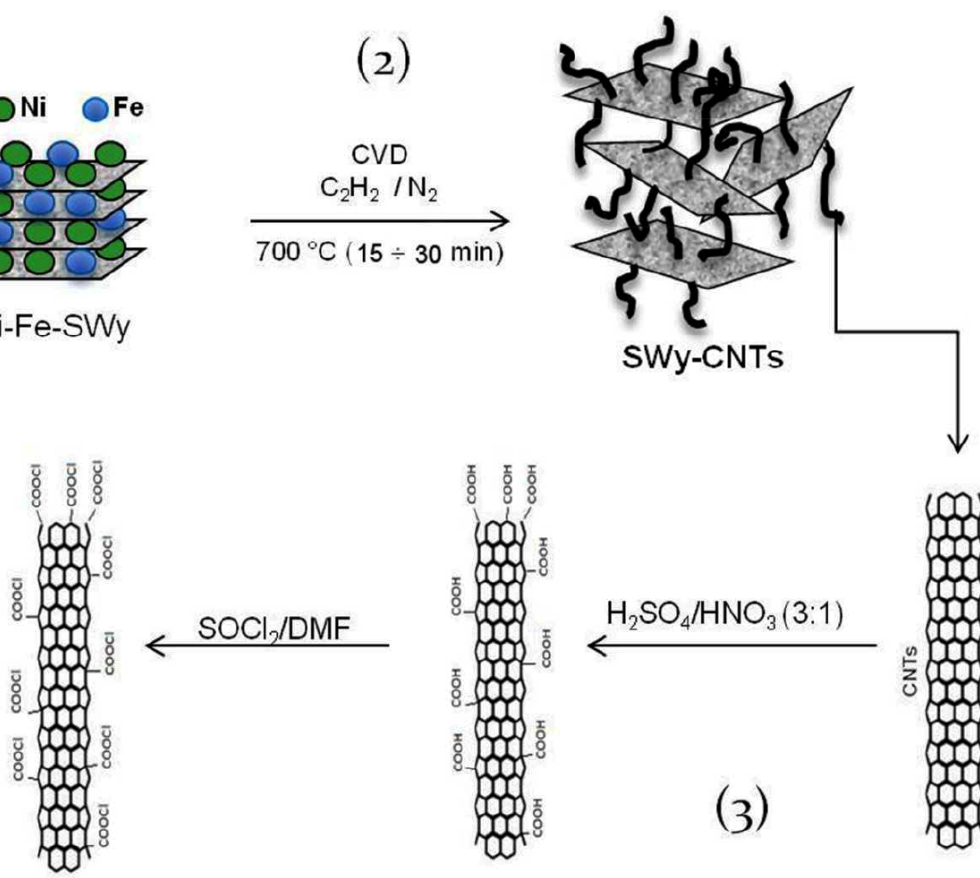

SWy-OxCNTS

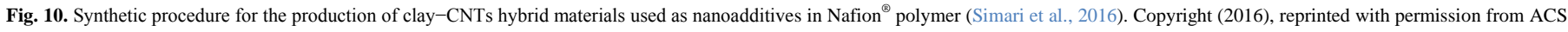




\subsection{Nanocomposite PEMs with other miscellaneous fillers}

Cellulose whiskers (CWs), has also been used as a filler to alter the transport properties of Nafion ${ }^{\circledR}$. These 1D nanoparticles with their unique properties such as high aspect ratio, excellent dispersibility in aqueous solvents owing to high surface charges, as well as high capacity to absorb and retain water, can improve proton conductivity, power density, and reduce methanol crossover in Nafion ${ }^{\circledR}-\mathrm{CW}$ nanocomposite membranes. These improvements are ascribed to the formation of long-range oriented conduction pathways in the vicinity of $1 \mathrm{D}$ cellulosic nanostructures as shown schematically in Figure 11 (Hasani-Sadrabadi et al., 2014b).

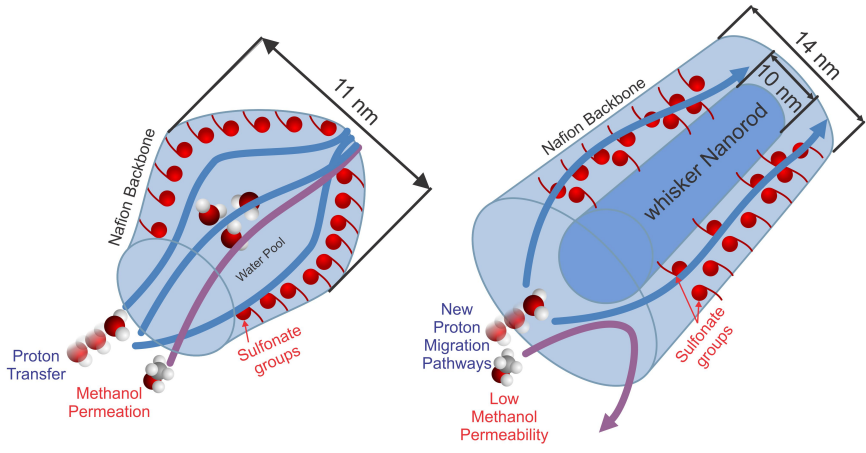

Nafion Nafion/Whisker Nanocomposite

Fig. 11. Schematic representation of the proposed mechanism for enhancement in proton migration as well as blocking methanol diffusion pathways in the presence of cellulose whiskers (Hasani-Sadrabadi et al., 2014b). Copyright (2016), reprinted with permission from RSC

Incorporation of $\mathrm{ZrO}_{2}$ as filler has also been investigated for PEMs. For instance, Zheng and Mathe (2011) found that a poly(2,5-benzimidazole) membrane filled with $\mathrm{ZrO}_{2}$ exhibited both higher proton conductivity $(0.069$ $\mathrm{S} \mathrm{cm}{ }^{-1}$ at $100{ }^{\circ} \mathrm{C}$ ) as well as higher thermal and mechanical stability, compared with an unfilled membrane. Incorporating a porous hygroscopic filler with tubular morphology into a Nafion ${ }^{\circledR}$ membrane could also be an effective approach to enhance the performance of Nafion ${ }^{\circledR}$ membranes operated under fully humid and low RH conditions (Matos et al., 2007; Jun et al., 2011). In line with that, Ketpang et al. (2014) incorporated porous $\mathrm{ZrO}_{2}$ nanotube $(\mathrm{ZrNT})$ into a Nafion ${ }^{\circledR}$ matrix, and the resultant nanocomposite membrane exhibited 2.7 and 1.2 times higher power density at $0.6 \mathrm{~V}$, under $50 \%$ and $100 \% \mathrm{RH}$ at $80{ }^{\circ} \mathrm{C}$, respectively.

Graphitic carbon nitride $\left(\mathrm{g}-\mathrm{C}_{3} \mathrm{~N}_{4}\right)$ is also a promising 2-D soft nanomaterial with a similar stacked 2- D structure as graphene (Zheng et al., 2012; Xu et al., 2013), which is becoming increasingly popular in the fields of photocatalysis, heterogeneous catalysis, etc. (Shinde et al., 2015; Wen et al., 2015; Li et al., 2016). g- $\mathrm{C}_{3} \mathrm{~N}_{4}$ can be employed as potential filler for PEMs to enhance their performance by forming acid-base pairs between the amino ($\mathrm{NH}_{2}$ ) and imino $(-\mathrm{NH})$ groups of $\mathrm{g}-\mathrm{C}_{3} \mathrm{~N}_{4}$ and by interacting with the acid groups (sulfonate groups) in the polymer matrix

Recently, Gang et al. (2016) explored $\mathrm{g}_{-} \mathrm{C}_{3} \mathrm{~N}_{4} / \mathrm{SPEEK}$ nanocomposite membrane for DMFC applications and achieved a 39\% increase in maximum power density and $68 \%$ increase in ultimate tensile strength. Among various inorganic fillers, zirconium phosphate $\left(\mathrm{Zr}\left(\mathrm{HPO}_{4}\right) 2 . \mathrm{H}_{2} \mathrm{O}\right)(\mathrm{ZrP})$, an acidic filler containing phosphonic acids $\left(\mathrm{HPO}_{4}\right)$, has the ability to donate protons and is thermally stable at temperatures above $180^{\circ} \mathrm{C}$ (Truffier-Boutry et al., 2007). Moreover, it can increase the mobility of protons on its surface and thus the conductivity (Truffier-Boutry et al., 2007), and therefore, has been used as a doping material to improve Nafion ${ }^{\circledast}$ membrane properties (Bauer and WillertPorada, 2004; Alberti et al., 2007). In fact, zirconium phosphate (ZrP) represent a series of layered structures of two forms, $\alpha-\mathrm{ZrP}$ and $\gamma-\mathrm{ZrP}$. Both structures can be exfoliated to produce suspensions of lamella in a variety of solvents suitable for inclusion into composite membranes (Alberti and Casciola, 2003). Pica et al. (2012) studied mechanical properties and proton conductivity of short-side-chain perfluorosulfonic acid membranes filled with different amounts of $\mathrm{ZrP}$ nanoparticles. Their results showed a significant increase in the Young's modulus (up to $80 \%$ ) and in the yield stress (up to
$124 \%$ ) not only under ambient conditions but also at $80{ }^{\circ} \mathrm{C}$ and $80 \% \mathrm{RH}$ in comparison with the neat polymer. S40(sulfonated poly(styrene-block(ethylene-ran-butylene)-block-styrene) with $40 \%$ degree of sulfonation)$\mathrm{ZrP}$ composite membranes were prepared via precursor infiltration method by Liu et al. (2015). The composite membrane containing 3 wt.\% of $\mathrm{ZrP}$ indicated a remarkable 16 fold increment in selectivity as compared with the parent S40 membrane. Moreover, these membranes also demonstrated a power density of $66 \mathrm{~mW} \mathrm{~cm} \mathrm{~cm}^{-2}$ and a maximum current density of $450 \mathrm{~mA} \mathrm{~cm}{ }^{-2}$ without cathode flooding (Liu et al. 2015).

\section{Conclusions}

As stated, the Nafion ${ }^{\circledR}$ membrane due to its disadvantages is the main obstacle to further improvements of FCs. Hybrid organic-inorganic membranes consisting of a polymeric material combined with an inorganic filler, could be of significant help to overcome these shortcomings. The inorganic fillers mainly used include hygroscopic oxides, ZrP, silane-based fillers, GO, MOFs, clays, CNTs, zeolites, and PTA. In fact, these membranes combine the intrinsic physical and chemical properties of both the inorganic and organic segments. In hybric membranes, the inorganic segment provides high mechanical and therma stability, while also suppress fuel crossover. On the other hand, the organic segment provides flexibility. The properties of polymer composites depend on the type of nanoparticles incorporated, their size and shape, their concentration, and their interactions with the polymer matrix.

\section{References}

[1] Ahmad, H., Kamarudin, S.K., Hasran, U.A., Daud, W.R.W., 2010 Overview of hybrid membranes for direct-methanol fuel-cel applications. Int. J. Hydrogen Energy. 35(5), 2160-2175.

[2] Alberti, G., Casciola, M., 2003. Composite membranes for mediumtemperature PEM fuel cells. Annu. Rev. Mater. Res. 33(1),129-154.

[3] Alberti, G., Casciola, M., Capitani, D., Donnadio, A., Narducci, R., Pica, M., Sganappa, M., 2007. Novel Nafion-zirconium phosphate nanocomposite membranes with enhanced stability of proton conductivity at medium temperature and high relative humidity. Electrochim. Acta. 52(28), 8125-8132.

[4] Amirinejad, M., Madaeni, S.S., Lee, K.S., Ko, U., Rafiee, E., Lee, J.S., 2012. Sulfonated poly(arylene ether)/heteropolyacids nanocomposite membranes for proton exchange membrane fuel cells. Electrochim. Acta. 62, 227-233

[5] Amirinejad, M., Madaeni, S.S., Rafiee, E., Amirinejad, S., 2011 Cesium hydrogen salt of heteropolyacids/Nafion nanocomposite membranes for proton exchange membrane fuel cells. J. Membr. Sci. 377(1-2), 89-98

[6] Amjadi, M., Rowshanzamir, S., Peighambardoust, S.J., Hosseini, M.G., Eikani, M.H., 2010. Investigation of physical properties anc cell performance of $\mathrm{Nafion} / \mathrm{TiO}_{2}$ nanocomposite membranes for high temperature PEM fuel cells. Int. J. Hydrogen Energy. 35(17), 9252-9260.

[7] An, L., Zhao, T.S., Wu, Q.X., Zeng, L., 2012. Comparison of different types of membrane in alkaline direct ethanol fuel cells. Int. J. Hydrogen Energy. 37(19), 14536-14542.

[8] Asgari, M.S., Nikazar, M., Molla-Abbasi, P., Hasani-Sadrabadi, M.M., 2013. Nafion ${ }^{\circledast} /$ histidine functionalized carbon nanotube: High-performance fuel cell membranes. Int. J. Hydrogen Energy. 38(14), 5894-5902

[9] Aslan, A., Bozkurt, A., 2014. Nanocomposite membranes based on sulfonated polysulfone and sulfated nano-titania/NMPA for proton exchange membrane fuel cells. Solid State Ionics. 255, 89-95.

[10] Auimviriyavat, J., Changkhamchom, S., Sirivat, A., 2011 Development of poly (ether ether ketone) (Peek) with inorganic filler for direct methanol fuel cells (DMFCS). Ind. Eng. Chem. Res. 50(22), 12527-12533

[11] Authayanun, S., Im-orb, K., Arpornwichanop, A., 2015. A review of the development of high temperature proton exchange membrane fuel cells. Chin. J. Catal. 36(4), 473-483. 
[12] Awang, N., Ismail, A.F., Jaafar, J., Matsuura, T., Junoh, H., Othman, M.H.D., Rahman, M.A., 2015. Functionalization of polymeric materials as a high performance membrane for direct methanol fuel cell: a review. React. Funct. Polym. 86, 248-258.

[13] Badwal, S.P.S., Giddey, S., Kulkarni, A., Goel, J., Basu, S., 2015. Direct ethanol fuel cells for transport and stationary applications-a comprehensive review. Appl. Energy. 145, 80-103.

[14] Bauer, F., Willert-Porada, M., 2004. Microstructural characterization of Zr-phosphate-Nafion ${ }^{\circledR}$ membranes for direct methanol fuel cell (DMFC) applications. J. Membr. Sci. 233(1-2), 141-149.

[15] Bayer, T., Bishop, S.R., Nishihara, M., Sasaki, K., Lyth, S.M., 2014. Characterization of a graphene oxide membrane fuel cell. J. Power Sources. 272, 239-247

[16] Beydaghi, H., Javanbakht, M., Bagheri, A., Salarizadeh, P., GhafarianZahmatkesh, H., Kashefi, S., Kowsari, E., 2015. Novel nanocomposite membranes based on blended sulfonated poly (ether ether ketone)/poly (vinyl alcohol) containing sulfonated graphene oxide $/ \mathrm{Fe}_{3} \mathrm{O}_{4}$ nanosheets for DMFC applications. RSC Adv. 5(90), 74054-74064.

[17] Beydaghi, H., Javanbakht, M., 2015. Aligned nanocomposite membranes containing sulfonated graphene oxide with superior ionic conductivity for direct methanol fuel cell application. Ind. Eng. Chem. Res. 54(28) 7028-7037.

[18] Bose, S., Kuila, T., Nguyen, T.X.H., Kim, N.H., Lau, K.T., Lee, J.H., 2011. Polymer membranes for high temperature proton exchange membrane fuel cell: recent advances and challenges. Prog. Polym. Sci. 36(6), 813-843.

[19] Brijmohan, S.B., Shaw, M.T., 2007. Magnetic ion-exchange nanoparticles and their application in proton exchange membranes. J. Membr. Sci. 303(1-2), 64-71

[20] Bounor-Legaré, V., Cassagnau, P., 2014. In situ synthesis of organicinorganic hybrids or nanocomposites from sol-gel chemistry in molten polymers. Prog. Polym. Sci. 39(8), 1473-1497.

[21] Bureekaew, S., Horike, S., Higuchi, M., Mizuno, M., Kawamura, T., Tanaka, D., Yanai, N., Kitagawa, S., 2009. One-dimensional imidazole aggregate in aluminium porous coordination polymers with high proton conductivity. Nat. Mater. 8(10), 831-836.

[22] Buquet, C.L., Fatyeyeva, K., Poncin-Epaillard, F., Schaetzel, P., Dargent, E., Langevin, D., Nguyen, Q.T., Marais, S., 2010. New hybrid membranes for fuel cells: plasma treated laponite based sulfonated polysulfone. J. Membr. Sci. 351(1-2), 1-10.

[23] Carrette, L., Friedrich, K.L., Stimming, U., 2001. Fuel cellsfundamentals and applications. Fuel cells. 1(1), 5-39.

[24] Chandan, A., Hattenberger, M., El-Kharouf, A., Du, S., Dhir, A., Self, V., Pollet, B.G., Ingram, A., Bujalski, W., 2013. High temperature (HT) polymer electrolyte membrane fuel cells (PEMFC)-a review. J. Power Sources. 231, 264-278.

[25] Chang, C.M., Liu, Y.L., Lee, Y.M., 2011. Polybenzimidazole membranes modified with polyelectrolyte-functionalized multiwalled carbon nanotubes for proton exchange membrane fuel cells. J. Mater. Chem. 21(20), 7480-7486

[26] Chen, Z., Holmberg, B., Li, W., Wang, X., Deng, W., Munoz, R., Yan, Y., 2006. Nafion/zeolite nanocomposite membrane by in situ crystallization for a direct methanol fuel cell. Chem. Mater. 18(24), 5669-5675.

[27] Chen, Z., Li, S., Yan, Y., 2005. Synthesis of template-free zeolite nanocrystals by reverse microemulsion-microwave method. Chem. Mater. 17(9), 2262-2266

[28] Chien, H.C., Tsai, L.D., Huang, C.P., Kang, C.Y., Lin, J.N., Chang, F.C., 2013. Sulfonated graphene oxide/Nafion composite membranes for high-performance direct methanol fuel cells. Int. J. hydrogen energy. 38(31), 13792-13801

[29] Choi, J., Kim, D.H., Kim, H.K., Shin, C., Kim, S.C., 2008. Polymer blend membranes of sulfonated poly (arylene ether ketone) for direct methanol fuel cell. J. Membr. Sci. 310(1), 384-392.

[30] Chomoucka, J., Drbohlavova, J., Huska, D., Adam, V., Kizek, R., Hubalek, J., 2010. Magnetic nanoparticles and targeted drug delivering. Pharmacol. Res. 62(2), 144-149.

[31] Cozzi, D., de Bonis, C., D'Epifanio, A., Mecheri, B., Tavares, A.C., Licoccia, S., 2014. Organically functionalized titanium oxide/Nafion composite proton exchange membranes for fuel cells applications. J. Power Sources. 248, 1127-1132

[32] Cui, L., Geng, Q., Gong, C., Liu, H., Zheng, G., Wang, G., Liu, Q. Wen, S., 2015. Novel sulfonated poly (ether ether ketone)/silica coated carbon nanotubes high-performance composite membranes for direct methanol fuel cell. Polym. Adv. Technol. 26(5), 457-464.

[33] Das, S., Kumar, P., Dutta, K., Kundu, P.P., 2014. Partial sulfonation of PVdF-co-HFP: a preliminary study and characterization for application in direct methanol fuel cell. Appl. Energy. 113, 169-177.

[34] Decher, G., Eckle, M., Schmitt, J., Struth, B., 1998. Layer-by-layer assembled multicomposite films. Curr. Opin. Colloid Interface Sci. 3(1), 32-39.

[35] Decher, G., 1997. Fuzzy nanoassemblies: toward layered polymeric multicomposites. Science. 277(5330), 1232-1237.

[36] Devrim, Y., Albostan, A., 2015. Enhancement of PEM fuel cel performance at higher temperatures and lower humidities by high performance membrane electrode assembly based on Nafion/zeolite membrane. Int. J. Hydrogen Energy. 40(44), 15328-15335.

[37] Di, Z., Xie, Q., Li, H., Mao, D., Li, M., Zhou, D., Li, L., 2015 Novel composite proton-exchange membrane based on protonconductive glass powders and sulfonated poly (ether ether ketone) J. Power Sources. 273, 688-696.

[38] Duan, C., Wei, M., Guo, D., He, C., Meng, Q., 2009. Crystal structures and properties of large protonated water clusters encapsulated by metal-organic frameworks. J. Am. Chem. Soc 132(10), 3321-3330.

[39] Dupuis, A.C., 2011. Proton exchange membranes for fuel cells operated at medium temperatures: materials and experimental techniques. Prog. Mater. Sci. 56(3), 289-327.

[40] Dutta, K., Das, S., Kundu, P.P., 2015. Partially sulfonated polyaniline induced high ion-exchange capacity and selectivity of Nafion membrane for application in direct methanol fuel cells. J. Membr. Sci. 473, 94-101.

[41] Dyer, A., 1988. An introduction to zeolite molecular sieves. John Wiley \& Sons, Chichester, ISBN 0471919810.

[42] Erkartal, M., Usta, H., Citir, M., Sen, U., 2016. Proton conducting poly (vinyl alcohol) (PVA)/poly (2-acrylamido-2-methylpropane sulfonic acid) (PAMPS)/zeolitic imidazolate framework (ZIF) ternary composite membrane. J. Membr. Sci. 499, 156-163.

[43] Escudero-Cid, R., Montiel, M., Sotomayor, L., Loureiro, B., Fatás, E., Ocón, P., 2015. Evaluation of polyaniline-Nafion ${ }^{\circledR}$ composite membranes for direct methanol fuel cells durability tests. Int. J. Hydrogen Energy. 40(25), 8182-8192

[44] Farhat, T.R., Hammond, P.T., 2006. Engineering ionic and electronic conductivity in polymer catalytic electrodes using the layer-by-layer technique. Chem. Mater. 18(1), 41-49

[45] Farrukh, A., Ashraf, F., Kaltbeitzel, A., Ling, X., Wagner, M. Duran, H., Ghaffar, A., ur Rehman, H., Parekh, S.H., Domke, K.F., Yameen, B., 2015. Polymer brush functionalized $\mathrm{SiO}_{2}$ nanoparticle based Nafion nanocomposites: a novel avenue to low-humidity proton conducting membranes. Polym. Chem. 6(31), 5782-5789.

[46] Feng, K., Tang, B., Wu, P., 2014. Sulfonated graphene oxide-silica for highly selective Nafion-based proton exchange membranes. J Mater. Chem. A. 2(38), 16083-16092

[47] Gandhi, K., Dixit, B.K., Dixit, D.K., 2012. Effect of addition of zirconium tungstate, lead tungstate and titanium dioxide on the proton conductivity of polystyrene porous membrane. Int. J. Hydrogen Energy. 37(4), 3922-3930.

[48] Gang, M., He, G., Li, Z., Cao, K., Li, Z., Yin, Y., Wu, H., Jiang, Z., 2016. Graphitic carbon nitride nanosheets/sulfonated poly (ether ether ketone) nanocomposite membrane for direct methanol fuel cell application. J. Membr. Sci. 507, 1-11.

[49] Gil, M., Ji, X., Li, X., Na, H., Hampsey, J.E., Lu, Y., 2004. Direc synthesis of sulfonated aromatic poly (ether ether ketone) proton exchange membranes for fuel cell applications. J. Membr. Sci. 234(1-2), 75-81

[50] Gögebakan, Z., Yücel, H., Culfaz, A., 2007. Crystallization field and rate study for the synthesis of Ferrierite. Ind. Eng. Chem. Res. 46(7), 2006-2012 
[51] Hasanabadi, N., Ghaffarian, S.R., Hasani-Sadrabadi, M.M., 2011. Magnetic field aligned nanocomposite proton exchange membranes based on sulfonated poly (ether sulfone) and $\mathrm{Fe}_{2} \mathrm{O}_{3}$ nanoparticles for direct methanol fuel cell application. Int. J. Hydrogen Energy. 36(23), 15323-15332.

[52] Hasanabadi, N., Ghaffarian, S.R., Hasani-Sadrabadi, M.M., 2013. Nafion-based magnetically aligned nanocomposite proton exchange membranes for direct methanol fuel cells. Solid State Ionics. 232, 58-67.

[53] Hasani-Sadrabadi, M.M., Dashtimoghadam, E., Majedi, F.S., Kabiri, K., Mokarram, N., Solati-Hashjin, M., Moaddel, H., 2010. Novel highperformance nanohybrid polyelectrolyte membranes based on biofunctionalized montmorillonite for fuel cell applications. Chem. Commun. 46(35), 6500-6502.

[54] Hasani-Sadrabadi, M.M., Dashtimoghadam, E., Majedi, F.S., Moaddel, H., Bertsch, A., Renaud, P., 2013. Superacid-doped polybenzimidazoledecorated carbon nanotubes: a novel high-performance proton exchange nanocomposite membrane. Nanoscale. 5(23), 11710-11717.

[55] Hasani-Sadrabadi, M.M., Majedi, F.S., Coullerez, G., Dashtimoghadam, E., VanDersarl, J.J., Bertsch, A., Moaddel, H., Jacob, K.I., Renaud, P., 2014a. Magnetically aligned nanodomains: application in highperformance ion conductive membranes. ACS Appl. Mater. Interfaces. 6(10), 7099-7107.

[56] Hasani-Sadrabadi, M.M., Dashtimoghadam, E., Nasseri, R., Karkhaneh, A., Majedi, F.S., Mokarram, N., Renaud, P., Jacob, K.I., 2014b. Cellulose nanowhiskers to regulate the microstructure of perfluorosulfonate ionomers for high-performance fuel cells. J. Mater. Chem. A. 2(29), 11334-11340

[57] Hasani-Sadrabadi, M.M., Dashtimoghadam, E., Majedi, F.S., VanDersarl, J.J., Bertsch, A., Renaud, P., Jacob, K.I., 2016. Ionic nanopeapods: next-generation proton conducting membranes based on phosphotungstic acid filled carbon nanotube. Nano Energy. 23, 114-121.

[58] He, G., He, X., Wang, X., Chang, C., Zhao, J., Li, Z., Wu, H., Jiang, Z., 2016. A highly proton-conducting, methanol-blocking Nafion composite membrane enabled by surface-coating crosslinked sulfonated graphene oxide. Chem. Commun. 52(10), 2173-2176.

[59] He, S., Jia, H., Lin, Y., Qian, H., Lin, J., 2015. Effect of clay modification on the structure and properties of sulfonated poly (ether ether ketone)/clay nanocomposites. Polym. Compos. 37(9), 2632-2638.

[60] He, Y., Wang, J., Zhang, H., Zhang, T., Zhang, B., Cao, S., Liu, J., 2014. Polydopamine-modified graphene oxide nanocomposite membrane for proton exchange membrane fuel cell under anhydrous conditions. J. Mater. Chem. A. 2(25), 9548-9558.

[61] Hickner, M.A., Ghassemi, H., Kim, Y.S., Einsla, B.R., McGrath, J.E., 2004. Alternative polymer systems for proton exchange membranes (PEMs). Chem. Rev. 104(10), 4587-4612.

[62] Holmberg, B.A., Hwang, S.J., Davis, M.E., Yan, Y., 2005. Synthesis and proton conductivity of sulfonic acid functionalized zeolite BEA nanocrystals. Microporous Mesoporous Mater. 80(1-3), 347-356.

[63] Hooshyari, K., Javanbakht, M., Shabanikia, A., Enhessari, M., 2015. Fabrication $\mathrm{BaZrO}_{3} / \mathrm{PBI}$-based nanocomposite as a new proton conducting membrane for high temperature proton exchange membrane fuel cells. J. Power Sources. 276, 62-72.

[64] Hooshyari, K., Javanbakht, M., Naji, L., Enhessari, M., 2014. Nanocomposite proton exchange membranes based on Nafion containing $\mathrm{Fe}_{2} \mathrm{TiO}_{5}$ nanoparticles in water and alcohol environments for PEMFC. J. Membr. Sci. 454, 74-81.

[65] Hudiono, Y., Choi, S., Shu, S., Koros, W.J., Tsapatsis, M., Nair, S., 2009. Porous layered oxide/Nafion ${ }^{\circledR}$ nanocomposite membranes for direct methanol fuel cell applications. Microporous Mesoporous Mater. 118(1-3), 427-434

[66] Hurd, J.A., Vaidhyanathan, R., Thangadurai, V., Ratcliffe, C.I., Moudrakovski, I.L., Shimizu, G.K., 2009. Anhydrous proton conduction at $150 \mathrm{C}$ in a crystalline metal-organic framework. Nat. Chem. 1(9), 705710.

[67] Jaafar, J., Ismail, A.F., Matsuura, T., 2009. Preparation and barrier properties of SPEEK/Cloisite $15 \mathrm{~A}^{\circledR} / \mathrm{TAP}$ nanocomposite membrane for DMFC application. J. Membr. Sci. 345(1), 119-127.

[68] Jacobson, M.Z., Colella, W.G., Golden, D.M., 2005. Cleaning the air and improving health with hydrogen fuel-cell vehicles. Science. 308(5730), 1901-1905
[69] Jalani, N.H., Dunn, K., Datta, R., 2005. Synthesis and characterization of Nafion ${ }^{\circledR}-\mathrm{MO}_{2}(\mathrm{M}=\mathrm{Zr}$, Si, Ti) nanocomposite membranes for higher temperature PEM fuel cells. Electrochim. Acta. 51(3), 553-560.

[70] Jana, K.K., Charan, C., Shahi, V.K., Mitra, K., Ray, B., Rana, D. Maiti, P., 2015. Functionalized poly (vinylidene fluoride) nanohybrid for superior fuel cell membrane. J. Membr. Sci. 481 124-136

[71] Jiang, S.P., Liu, Z., Tian, Z.Q., 2006. Layer-by-layer self-assembly of composite polyelectrolyte-Nafion membranes for direct methano fuel cells. Adv. Mater. 18(8), 1068-1072.

[72] Jones, C.W., Tsuji, K., Davis, M.E., 1998. Organic-functionalized molecular sieves as shape-selective catalysts. Nature. 393(6680), 52 54.

[73] Jun, Y., Zarrin, H., Fowler, M., Chen, Z., 2011. Functionalized titania nanotube composite membranes for high temperature proton exchange membrane fuel cells. Int. J. Hydrogen Energy. 36(10), 6073-6081.

[74] Jung, U.H., Park, K.T., Park, E.H., Kim, S.H., 2006. Improvement of low-humidity performance of PEMFC by addition of hydrophilic $\mathrm{SiO}_{2}$ particles to catalyst layer. J. Power Sources. 159(1), 529-532.

[75] Kango, S., Kalia, S., Celli, A., Njuguna, J., Habibi, Y., Kumar, R., 2013. Surface modification of inorganic nanoparticles for development of organic-inorganic nanocomposites-a review. Prog. Polym. Sci. 38(8), 1232-1261

[76] Kannan, R., Aher, P.P., Palaniselvam, T., Kurungot, S., Kharul, U.K., Pillai, V.K., 2010. Artificially designed membranes using phosphonated multiwall carbon nanotube-polybenzimidazole composites for polymer electrolyte fuel cells. J. Phys. Chem. Lett. 1(14), 2109-2113.

[77] Kannan, R., Kagalwala, H.N., Chaudhari, H.D., Kharul, U.K. Kurungot, S., Pillai, V.K., 2011. Improved performance of phosphonated carbon nanotube-polybenzimidazole composite membranes in proton exchange membrane fuel cells. J. Mater. Chem. 21(20), 7223-7231.

[78] Ketpang, K., Lee, K., Shanmugam, S., 2014. Facile synthesis of porous metal oxide nanotubes and modified Nafion composite membranes for polymer electrolyte fuel cells operated under low relative humidity. ACS Appl. Mater. Interfaces. 6(19), 16734-16744.

[79] Kim, D.J., Jo, M.J., Nam, S.Y., 2015. A review of polymernanocomposite electrolyte membranes for fuel cell application. J. Ind. Eng. Chem. 21, 36-52.

[80] Kim, D.W., Choi, H.S., Lee, C., Blumstein, A., Kang, Y., 2004 Investigation on methanol permeability of Nafion modified by selfassembled clay-nanocomposite multilayers. Electrochim. Acta 50(2-3), 659-662.

[81] Kim, J.Y., Mulmi, S., Lee, C.H., Park, H.B., Chung, Y.S., Lee, Y.M., 2006. Preparation of organic-inorganic nanocomposite membrane using a reactive polymeric dispersant and compatibilizer: proton and methanol transport with respect to nano-phase separated structure. J. Membr. Sci. 283(1-2), 172-181.

[82] Kim, Y., Ketpang, K., Jaritphun, S., Park, J.S., Shanmugam, S. 2015. A polyoxometalate coupled graphene oxide-Nafion composite membrane for fuel cells operating at low relative humidity. J. Mater. Chem. A. 3(15), 8148-8155.

[83] Kraytsberg, A., Ein-Eli, Y., 2014. Review of advanced materials for proton exchange membrane fuel cells. Energy Fuels. 28(12), 73037330.

[84] Kumar, G.G., Uthirakumar, P., Nahm, K.S., Elizabeth, R.N., 2009. Fabrication and electro chemical properties of poly vinyl alcohol/para toluene sulfonic acid membranes for the applications of DMFC. Solid State Ionics. 180(2), 282-287.

[85] Kumar, R., Mamlouk, M., Scott, K., 2014. Sulfonated polyether ether ketone-sulfonated graphene oxide composite membranes for polymer electrolyte fuel cells. RSC Adv. 4(2), 617-623.

[86] Kornatowski, J., 2005. Expressiveness of adsorption measurements for characterization of zeolitic materials-a review. Adsorption. $11(3), 275-293$. 
[87] Kourasi, M., Wills, R.G.A., Shah, A.A., Walsh, F.C., 2014. Heteropolyacids for fuel cell applications. Electrochim. Acta. 127, 454466.

[88] Laberty-Robert, C., Valle, K., Pereira, F., Sanchez, C., 2011. Design and properties of functional hybrid organic-inorganic membranes for fuel cells. Chem. Soc. Rev. 40(2), 961-1005.

[89] Laurent, S., Dutz, S., Häfeli, U.O., Mahmoudi, M., 2011. Magnetic fluid hyperthermia: focus on superparamagnetic iron oxide nanoparticles. Adv. Colloid Interface Sci. 166(1-2), 8-23

[90] Libby, B., Smyrl, W.H., Cussler, E.L., 2003. Polymer-zeolite composite membranes for direct methanol fuel cells. AIChE J. 49(4), 991-1001.

[91] Li, S.L., Xu, Q., 2013. Metal-organic frameworks as platforms for clean energy. Energy Environ. Sci. 6(6), 1656-1683.

[92] Li, T., Yang, Y., 2009. A novel inorganic/organic composite membrane tailored by various organic silane coupling agents for use in direct methanol fuel cells. J. Power Sources. 187(2), 332-340.

[93] Li, Q., Zhang, H., Tu, Z., Yu, J., Xiong, C., Pan, M., 2012. Impregnation of amine-tailored titanate nanotubes in polymer electrolyte membranes. J. Membr. Sci. 423-424, 284-292.

[94] Liu, K.L., Lee, H.C., Wang, B.Y., Lue, S.J., Lu, C.Y., Tsai, L.D., Fang, J., Chao, C.Y., 2015. Sulfonated poly (styrene-block-(ethylene-ranbutylene)-block-styrene (SSEBS)-zirconium phosphate (ZrP) composite membranes for direct methanol fuel cells. J. Membr. Sci. 495, 110-120.

[95] Livage, J., 2004. Basic principles of sol-gel chemistry, in Sol-Gel Technologies for Glass Producers and Users. Springer US, pp. 3-14.

[96] Li, Y., Jin, R., Fang, X., Yang, Y., Yang, M., Liu, X., Xing, Y., Song, S., 2016. In situ loading of $\mathrm{Ag}_{2} \mathrm{WO}_{4}$ on ultrathin $\mathrm{g}_{-} \mathrm{C}_{3} \mathrm{~N}_{4}$ nanosheets with highly enhanced photocatalytic performance. J. Hazard. Mater. 313, 219-228.

[97] Li, Y., He, G., Wang, S., Yu, S., Pan, F., Wu, H., Jiang, Z., 2013. Recent advances in the fabrication of advanced composite membranes. J. Mater. Chem. A. 1(35), 10058-10077.

[98] Li, Z., He, G., Zhao, Y., Cao, Y., Wu, H., Li, Y., Jiang, Z., 2014. Enhanced proton conductivity of proton exchange membranes by incorporating sulfonated metal-organic frameworks. J. Power Sources, $262,372-379$

[99] Liang, X., Zhang, F., Feng, W., Zou, X., Zhao, C., Na, H., Liu, C., Sun, F., Zhu, G., 2013. From metal-organic framework (MOF) to MOFpolymer composite membrane: enhancement of low-humidity proton conductivity. Chem. Sci. 4(3), 983-992.

[100]Luan, Y., Zhang, H., Zhang, Y., Li, L., Li, H., Liu, Y., 2008. Study on structural evolution of perfluorosulfonic ionomer from concentrated DMF-based solution to membranes. J. Membr. Sci. 319(1-2), 91-101.

[101]Lue, S.J., Pai, Y.L., Shih, C.M., Wu, M.C., Lai, S.M., 2015. Novel bilayer well-aligned Nafion/graphene oxide composite membranes prepared using spin coating method for direct liquid fuel cells. J. Membr. Sci. 493, 212-223

[102]Mahreni, A., Mohamad, A.B., Kadhum, A.A.H., Daud, W.R.W., Iyuke, S.E., 2009. Nafion/silicon oxide/phosphotungstic acid nanocomposite membrane with enhanced proton conductivity. J. Membr. Sci. 327(1-2), $32-40$.

[103]Maleki, A., Ghamari, N., Kamalzare, M., 2014. Chitosan-supported $\mathrm{Fe}_{3} \mathrm{O}_{4}$ nanoparticles: a magnetically recyclable heterogeneous nanocatalyst for the syntheses of multifunctional benzimidazoles and benzodiazepines. RSC Adv. 4(19), 9416-9423.

[104]Malers, J.L., Sweikart, M.A., Horan, J.L., Turner, J.A., Herring, A.M., 2007. Studies of heteropoly acid/polyvinylidenedifluoridehexafluoroproylene composite membranes and implication for the use of heteropoly acids as the proton conducting component in a fuel cell membrane. J. Power Sources. 172(1), 83-88

[105]Marx, S., van der Gryp, P., Neomagus, H., Everson, R., Keizer, K., 2002. Pervaporation separation of methanol from methanol/tert-amyl methyl ether mixtures with a commercial membrane. J. Membr. Sci. 209(2), 353-362

[106]Matos, B.R., Santiago, E.I., Fonseca, F.C., Linardi, M., Lavayen, V., Lacerda, R.G., Ladeira, L.O., Ferlauto, A.S., 2007. Nafion-titanate nanotube composite membranes for PEMFC operating at high temperature. J. Electrochem. Soc. 154(12), B1358-B1361.
[107]Mishra, A.K., Bose, S., Kuila, T., Kim, N.H., Lee, J.H., 2012. Silicate-based polymer-nanocomposite membranes for polymer electrolyte membrane fuel cells. Prog. Polym. Sci. 37(6), 842-869.

[108] Narayanamoorthy, B., Datta, K.K.R., Eswaramoorthy, M., Balaji, S. 2012. Improved oxygen reduction reaction catalyzed by pt/clay/Nafion nanocomposite for PEM fuel cells. ACS Appl. Mater. Interfaces. 4(7), 3620-3626.

[109]Neelakandan, S., Rana, D., Matsuura, T., Muthumeenal, A. Kanagaraj, P., Nagendran, A., 2014. Fabrication and electrochemical properties of surface modified sulfonated poly (vinylidenefluorideco-hexafluoropropylene) membranes for DMFC application. Solic State Ionics. 268, 35-41.

[110]Ng, E.P., Mintova, S., 2008. Nanoporous materials with enhanced hydrophilicity and high water sorption capacity. Microporous Mesoporous Mater. 114(1-3), 1-26.

[111] Ohkoshi, S.I., Nakagawa, K., Tomono, K., Imoto, K., Tsunobuchi, Y., Tokoro, H., 2010. High proton conductivity in prussian blue analogues and the interference effect by magnetic ordering. J. Am. Chem. Soc. 132(19), 6620-6621

[112] Oren, Y., Freger, V., Linder, C., 2004. Highly conductive ordered heterogeneous ion-exchange membranes. J. Membr. Sci. 239(1),1726.

[113] Ossiander, T., Heinzl, C., Gleich, S., Schönberger, F., Völk, P. Welsch, M., Scheu, C., 2014. Influence of the size and shape of silica nanoparticles on the properties and degradation of a PBI-based high temperature polymer electrolyte membrane. J. Membr. Sci. $454,12-19$

[114]Park, K.T., Jung, U.H., Choi, D.W., Chun, K., Lee, H.M., Kim, S.H., 2008. $\mathrm{ZrO}_{2}-\mathrm{SiO}_{2} / \mathrm{Nafion}^{\circledR}$ composite membrane for polymer electrolyte membrane fuel cells operation at high temperature and low humidity. J. Power Sources. 177(2), 247-253.

[115]Peighambardoust, S., Rowshanzamir, S., Amjadi, M., 2010. Review of the proton exchange membranes for fuel cell applications. Int. J Hydrogen Energy. 35(17), 9349-9384

[116]Pica, M., Donnadio, A., Casciola, M., Cojocaru, P., Merlo, L., 2012. Short side chain perfluorosulfonic acid membranes and their composites with nanosized zirconium phosphate: hydration, mechanical properties and proton conductivity. J. Mater. Chem. 22(47), 24902-24908.

[117]Pomogailo, A.D., 2005. Polymer sol-gel synthesis of hybric nanocomposites. Colloid J. 67(6), 658-677.

[118]Ramani, V., Kunz, H.R., Fenton, J.M., 2005. Stabilized composite membranes and membrane electrode assemblies for elevated temperature/low relative humidity PEFC operation. J. Power Sources. 152, 182-188.

[119]Ramani, V., Kunz, H.R., Fenton, J.M., 2005. Stabilized heteropolyacid/Nafion ${ }^{\circledR}$ composite membranes for elevated temperature/low relative humidity PEFC operation. Electrochim. Acta. 50(5), 1181-1187.

[120]Ramaswamy, P., Wong, N.E., Shimizu, G.K., 2014. MOFs as proton conductors-challenges and opportunities. Chem. Soc. Rev. 43(16), 5913-5932.

[121]Ren, S., Sun, G., Li, C., Song, S., Xin, Q., Yang, X., 2006. Sulfated zirconia-Nafion composite membranes for higher temperature direct methanol fuel cells. J. Power Sources. 157(2), 724-726.

[122]Ren, Y., Chia, G.H., Gao, Z., 2013. Metal-organic frameworks in fuel cell technologies. Nano Today. 8(6), 577-597.

[123]Rikukawa, M. Sanui, K., 2000. Proton-conducting polymer electrolyte membranes based on hydrocarbon polymers. Prog. Polym. Sci. 25(10), 1463-1502.

[124] Sacca, A., Gatto, I., Carbone, A., Pedicini, R., Passalacqua, E., 2006. $\mathrm{ZrO}_{2}$-Nafion composite membranes for polymer electrolyte fuel cells (PEFCs) at intermediate temperature. J. Power Sources. 163(1) 47-51.

[125] Saccà, A., Carbone, A., Pedicini, R., Marrony, M., Barrera, R. Elomaa, M., Passalacqua, E., 2008. Phosphotungstic acid supported on a nanopowdered $\mathrm{ZrO}_{2}$ as a filler in Nafion-based membranes for polymer electrolyte fuel cells. Fuel Cells. 8(3-4), 225-235. 
[126] Safari, J. Javadian, L., 2014. Chitosan decorated $\mathrm{Fe}_{3} \mathrm{O}_{4}$ nanoparticles as a magnetic catalyst in the synthesis of phenytoin derivatives. RSC Adv. 4(90), 48973-48979.

[127] Sakamoto, M., Nohara, S., Miyatake, K., Uchida, M., Watanabe, M., Uchida, H., 2014. Effects of incorporation of $\mathrm{SiO}_{2}$ nanoparticles into sulfonated polyimide electrolyte membranes on fuel cell performance under low humidity conditions. Electrochim. Acta. 137, 213-218.

[128] Sasikala, S., Meenakshi, S., Bhat, S.D., Sahu, A.K., 2014. Functionalized Bentonite clay-sPEEK based composite membranes for direct methanol fuel cells. Electrochim. Acta. 135, 232-241.

[129] Sgreccia, E., Chailan, J.F., Khadhraoui, M., Di Vona, M.L., Knauth, P., 2010. Mechanical properties of proton-conducting sulfonated aromatic polymer membranes: stress-strain tests and dynamical analysis. J. Power Sources. 195(23), 7770-7775

[130] Shabanikia, A., Javanbakht, M., Amoli, H.S., Hooshyari, K., Enhessari, M., 2015. Polybenzimidazole/strontium cerate nanocomposites with enhanced proton conductivity for proton exchange membrane fuel cells operating at high temperature. Electrochim. Acta. 154, 370-378.

[131] Shahi, V.K., 2007. Highly charged proton-exchange membrane: sulfonated poly (ether sulfone)-silica polyelectrolyte composite membranes for fuel cells. Solid State Ionics. 177(39-40), 3395-3404.

[132] Sharaf, O.Z. Orhan, M.F., 2014. An overview of fuel cell technology: fundamentals and applications. Renew. Sust. Energy Rev. 32, 810-853.

[133] Shinde, S., Sami, A., Lee, J.H., 2015. Electrocatalytic hydrogen evolution using graphitic carbon nitride coupled with nanoporous graphene co-doped by S and Se. J. Mater. Chem. A. 3(24), 1281012819.

[134]Silva, R.F., De Francesco, M., Pozio, A., 2004. Tangential and normal conductivities of Nafion ${ }^{\circledR}$ membranes used in polymer electrolyte fuel cells. J. Power Sources. 134(1), 18-26.

[135]Simari, C., Potsi, G., Policicchio, A., Perrotta, I., Nicotera, I., 2016. Clay-Carbon nanotubes hybrid materials for nanocomposite membranes: advantages of branched structure for proton transport under low humidity conditions in PEMFCs. J. Phys. Chem. C. 120(5), 2574-2584.

[136] Smitha, B., Sridhar, S., Khan, A.A., 2003. Synthesis and characterization of proton conducting polymer membranes for fuel cells. J. Membr. Sci. 225(1-2), 63-76.

[137] Steele, B.C., Heinzel, A., 2001. Materials for fuel-cell technologies. Nature. 414, 345-352.

[138]Sun, C., Lee, J.S., Zhang, M., 2008. Magnetic nanoparticles in MR imaging and drug delivery. Adv. Drug Delivery Rev. 60(11), 12521265.

[139]Tang, J., Yuan, W., Wang, J., Tang, J., Li, H., Zhang, Y., 2012. Perfluorosulfonate ionomer membranes with improved through-plane proton conductivity fabricated under magnetic field. J. Membr. Sci. 423424, 267-274.

[140]Thomassin, J.M., Kollar, J., Caldarella, G., Germain, A., Jérôme, R., Detrembleur, C., 2007. Beneficial effect of carbon nanotubes on the performances of Nafion membranes in fuel cell applications. J. Membr. Sci. 303(1-2), 252-257

[141]Tricoli, V., Nannetti, F., 2003. Zeolite-Nafion composites as ion conducting membrane materials. Electrochim. Acta. 48(18), 2625-2633.

[142]Tripathi, B.P. Shahi, V.K., 2011. Organic-inorganic nanocomposite polymer electrolyte membranes for fuel cell applications. Prog. Polym. Sci. 36(7), 945-979.

[143] Truffier-Boutry, D., De Geyer, A., Guetaz, L., Diat, O., Gebel, G., 2007. Structural study of zirconium phosphate-Nafion hybrid membranes for high-temperature proton exchange membrane fuel cell applications. Macromolecules. 40(23), 8259-8264.

[144]Tsai, C.H., Wang, C.C., Chang, C.Y., Lin, C.H., Chen-Yang, Y.W., 2014. Enhancing performance of Nafion ${ }^{\otimes}$-based PEMFC by 1-D channel metal-organic frameworks as PEM filler. Int. J. Hydrogen Energy. 39(28), 15696-15705.

[145]Wang, Y.J., Kim, D., 2007. Crystallinity, morphology, mechanical properties and conductivity study of in situ formed $\mathrm{PVdF} / \mathrm{LiClO}_{4} / \mathrm{TiO}_{2}$ nanocomposite polymer electrolytes. Electrochim. Acta. 52(9), 31813189.

[146] Wang, Y., Chen, K.S., Mishler, J., Cho, S.C., Adroher, X.C., 2011. A review of polymer electrolyte membrane fuel cells: technology, applications, and needs on fundamental research. Appl. Energy. 88(4), 981-1007.

[147]Wang, H., Huang, L., Holmberg, B.A., Yan, Y., 2002. Nanostructured zeolite 4A molecular sieving air separation membranes. Chem. Commun. (16), 1708-1709.

[148] Wang, H., Holmberg, B.A. Yan, Y., 2003. Synthesis of templatefree zeolite nanocrystals by using in situ thermoreversible polymer hydrogels. J. Am. Chem. Soc. 125(33), 9928-9929.

[149]Wang, L.S., Lai, A.N., Lin, C.X., Zhang, Q.G., Zhu, A.M., Liu, Q.L., 2015. Orderly sandwich-shaped graphene oxide/Nafion composite membranes for direct methanol fuel cells. J. Membr. Sci. 492, 58-66.

[150]Wen, P., Gong, P., Sun, J., Wang, J., Yang, S., 2015. Design and synthesis of Ni-MOF/CNT composites and $\mathrm{rGO} /$ carbon nitride composites for an asymmetric supercapacitor with high energy and power density. J. Mater. Chem. A. 3(26), 13874-13883.

[151]Won, J., Park, H.H., Kim, Y.J., Choi, S.W., Ha, H.Y., Oh, I.H., Kim, H.S., Kang, Y.S., Ihn, K.J., 2003. Fixation of nanosized proton transport channels in membranes. Macromolecules. 36(9), 3228 3234.

[152]Wu, B., Lin, X., Ge, L., Wu, L., Xu, T., 2013. A novel route for preparing highly proton conductive membrane materials with metalorganic frameworks. Chem. Commun. 49(2), 143-145.

[153]Wu, H., Cao, Y., Shen, X., Li, Z., Xu, T., Jiang, Z., 2014 Preparation and performance of different amino acids functionalized titania-embedded sulfonated poly (ether ether ketone) hybrid membranes for direct methanol fuel cells. J. Membr. Sci. 463, 134144.

[154]Wu, H., Cao, Y., Li, Z., He, G., Jiang, Z., 2015. Novel sulfonated poly (ether ether ketone)/phosphonic acid-functionalized titania nanohybrid membrane by an in situ method for direct methanol fuel cells. J. Power Sources. 273, 544-553.

[155]Xi, J., Wu, Z., Qiu, X., Chen, L., 2007. Nafion/ $/ \mathrm{SiO}_{2}$ hybrid membrane for vanadium redox flow battery. J. Power Sources 166(2), 531-536.

[156]Xu, T., Wu, D., Wu, L., 2008. Poly (2,6-dimethyl-1,4-phenylene oxide) (PPO)-a versatile starting polymer for proton conductive membranes (PCMs). Prog. Polym. Sci. 33(9), 894-915.

[157]Xu, J., Li, Y., Peng, S., Lu, G., Li, S., 2013. Eosin Y-sensitized graphitic carbon nitride fabricated by heating urea for visible light photocatalytic hydrogen evolution: the effect of the pyrolysis temperature of urea. Phys. Chem. Chem. Phys. 15(20), 7657-7665.

[158]Ye, D.H., Zhan, Z.G., 2013. A review on the sealing structures of membrane electrode assembly of proton exchange membrane fue cells. J. Power Sources. 231, 285-292.

[159] Yen, C.Y., Liao, S.H., Lin, Y.F., Hung, C.H., Lin, Y.Y., Ma, C.C.M., 2006. Preparation and properties of high performance nanocomposite bipolar plate for fuel cell. J. Power Sources. 162(1), 309-315

[160] Yoon, K.S., Choi, J.H., Hong, Y.T., Hong, S.K., Lee, S.Y., 2009 Control of nanoparticle dispersion in SPAES/ $/ \mathrm{SiO}_{2}$ composite proton conductors and its influence on DMFC membrane performance. Electrochem. Commun. 11(7),1492-1495

[161] Yuan, T., Pu, L., Huang, Q., Zhang, H., Li, X., Yang, H., 2014. An effective methanol-blocking membrane modified with graphene oxide nanosheets for passive direct methanol fuel cells. Electrochim. Acta. 117, 393-397.

[162]Yu, D.M., Sung, I.H., Yoon, Y.J., Kim, T.H., Lee, J.Y., Hong, Y.T., 2013. Properties of sulfonated poly (arylene ether sulfone)/functionalized carbon nanotube composite membrane for high temperature PEMFCs. Fuel Cells. 13(5), 843-850.

[163] Yun, S., Im, H., Heo, Y., Kim, J., 2011. Crosslinked sulfonated poly (vinyl alcohol)/sulfonated multi-walled carbon nanotubes nanocomposite membranes for direct methanol fuel cells. J. Membr. Sci. 380(1-2),208-215.

[164]Yun, S., Heo, Y., Im, H., Kim, J., 2012. Sulfonated multiwalled carbon nanotube/sulfonated poly (ether sulfone) composite membrane with low methanol permeability for direct methanol fuel cells. J. Appl. Polym. Sci. 126(S2). 
[165]Zhao, C., Lin, H., Cui, Z., Li, X., Na, H., Xing, W., 2009. Highly conductive, methanol resistant fuel cell membranes fabricated by layerby-layer self-assembly of inorganic heteropolyacid. J. Power Sources. 194(1), 168-174.

[166]Zhang, H., Ma, C., Wang, J., Wang, X., Bai, H., Liu, J., 2014. Enhancement of proton conductivity of polymer electrolyte membrane enabled by sulfonated nanotubes. Int. J. Hydrogen Energy. 39(2), 974986.

[167]Zhou, W., Xiao, J., Chen, Y., Zeng, R., Xiao, S., Nie, H., Li, F., Song, C., 2011. Sulfonated carbon nanotubes/sulfonated poly (ether sulfone ether ketone ketone) composites for polymer electrolyte membranes. Polym. Adv. Technol. 22(12), 1747-1752.

[168]Zhang, L., Chae, S.R., Hendren, Z., Park, J.S., Wiesner, M.R., 2012. Recent advances in proton exchange membranes for fuel cell applications. Chem. Eng. J. 204-206, 87-97.

[169]Zhang, X., 2007. Porous organic-inorganic hybrid electrolytes for hightemperature proton exchange membrane fuel cells. J. Electrochem. Soc. 154(3), B322-B326.

[170]Zakaria, Z., Kamarudin, S.K., Timmiati, S.N., 2016. Membranes for direct ethanol fuel cells: an overview. Appl. Energy. 163, 334-342.
[171]Zarrin, H., Higgins, D., Jun, Y., Chen, Z., Fowler, M., 2011 Functionalized graphene oxide nanocomposite membrane for low humidity and high temperature proton exchange membrane fuel cells. J. Phys. Chem. C. 115(42), 20774-20781.

[172]Zhai, Y., Zhang, H., Hu, J., Yi, B., 2006. Preparation and characterization of sulfated zirconia $\left(\mathrm{SO}_{4}{ }^{2}-/ \mathrm{ZrO}_{2}\right) / \mathrm{Nafion}$ composite membranes for PEMFC operation at high temperature/low humidity. J. Membr. Sci. 280(1-2), 148-155

[173]Zheng, Y., Liu, J., Liang, J., Jaroniec, M., Qiao, S.Z., 2012. Graphitic carbon nitride materials: controllable synthesis and applications in fuel cells and photocatalysis. Energy Environ. Sci. $5(5), 6717-6731$

[174]Zheng, H. Mathe, M., 2011. Enhanced conductivity and stability of composite membranes based on poly (2,5-benzimidazole) and zirconium oxide nanoparticles for fuel cells. J. Power Sources. 196(3), 894-898

[175]Zeng, R., Wang, Y., Wang, S., Shen, P.K., 2007. Homogeneous synthesis of PFSI/silica composite membranes for PEMFC operating at low humidity. Electrochim. Acta. 52(12), 3895-3900.

[176]Zimmerman, C.M., Singh, A., Koros, W.J., 1997. Tailoring mixed matrix composite membranes for gas separations. J. Membr. Sci 137(1-2), 145-154. 